\title{
وجه آخر لفكر ابن رشد: مواقف دينية وسياسية
}

\section{فؤاد بن أحمد}

$$
\begin{aligned}
& \text { الملخص } \\
& \text { اشتهر ابن رشد بدعوته إلى الارتقاء بالقول الفلسفي عن حيثيات التاريخي وملابسات الجزئي جاعلا من البرهان } \\
& \text { خطابه، ومن الإنسان بما هو إنسان مخاطبه. ومهمتنا في هذه الدراسة هي أن نذهب في البحاه آخر، لإثبات وجهه آخر }
\end{aligned}
$$

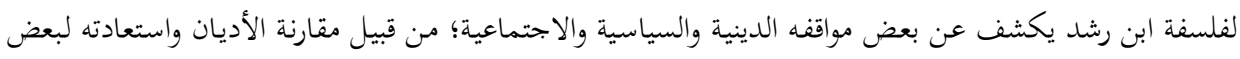

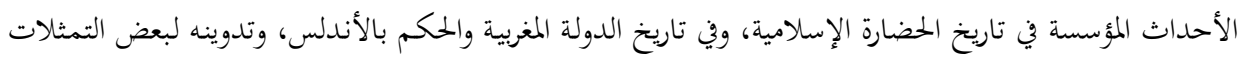

$$
\begin{aligned}
& \text { الاجتماعية السائدة في زمنه بخصوص العلاقات بين العرب والبربر. } \\
& \text { الغرض من البحث هو تتبع هذه التفاصيل التاريخية لفلسفة ابن رشد باعتبارها مدخلا لفهم طريقة تمثله وقراءته } \\
& \text { لبعض القضايا الدينية والأحداث التاريخية والظواهر الثقافية وطريقة استعادته لها في نصوصه. } \\
& \text { الكلمات المفتاحية: التمثيل، الواقع، التاريخ، الشاهد، الاستدلال. }
\end{aligned}
$$

\section{Another Side of Ibn Rushd's Thought: Religious and Political Positions}

\section{Abstract}

It is commonly known that Ibn Rushd separates the philosophical discourse from the circumstances of history and surroundings of the details, considering demonstration (Burhān) as an inherent property of his discourse, and Man to whom this discourse is addressed. The purpose of this study is to highlight some of Ibn Rushd's religious, political, and social positions. Examples of these are his study of comparative religion, reproduction of some of the foundational events in the history of Islamic Civilization, specifically history of Moroccan dynasties, and writing of social representations concerning the relationships between the Arabs and the Berbers. The article will review historical features of Ibn Rushd's philosophy, to understand his interpretations and reproduction of some religious issues, historical events, and cultural phenomena.

Keywords: representation, reality, history, evidence, inference.

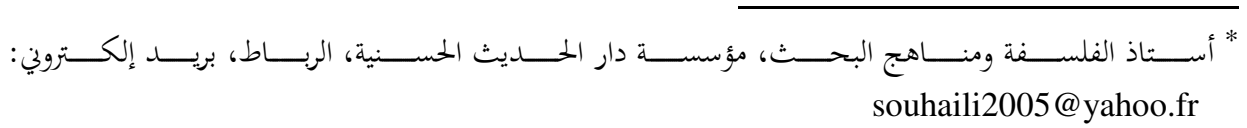

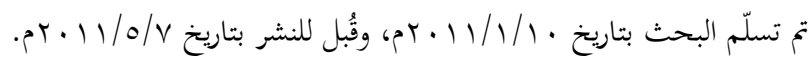




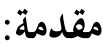

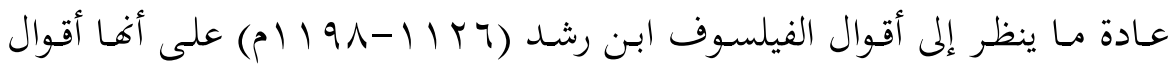
فلسفية تتسم بخصائص التجريد والعمومية والبعد عن الحيثيات التاريخية الطارئة والمتبدّلة؛

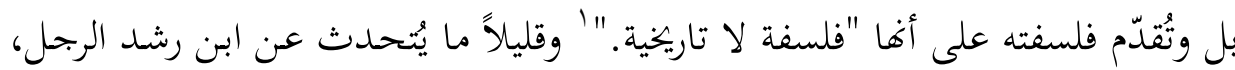

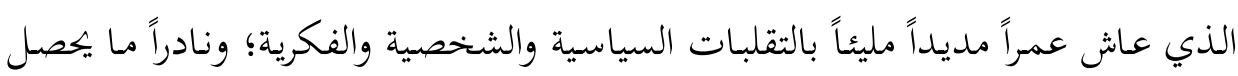

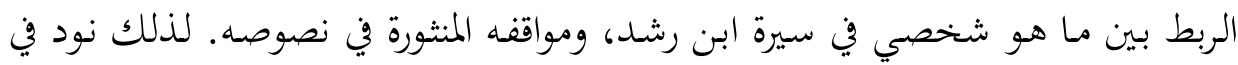

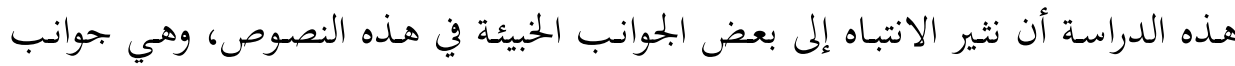

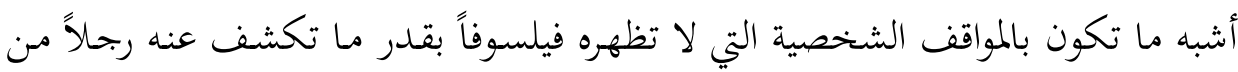

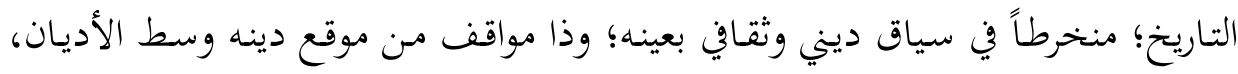

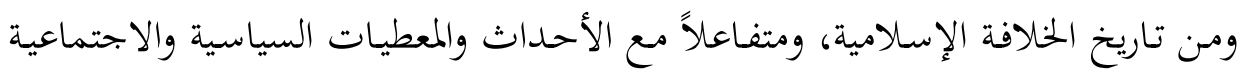
لدولته.

ونهن لا نقصد وضع دراسة تاريخية؛ لأنَّ ذلك لن يضيف شيئاً ذا بال لما هو مثبت

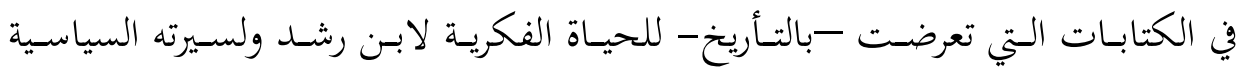

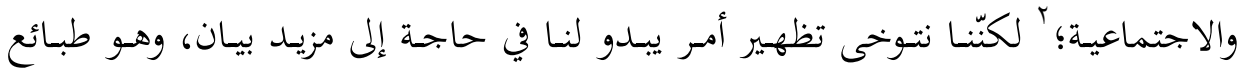

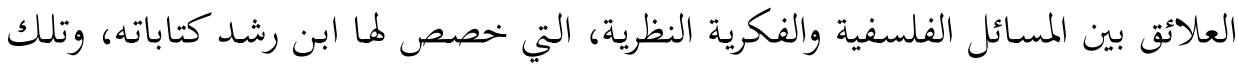

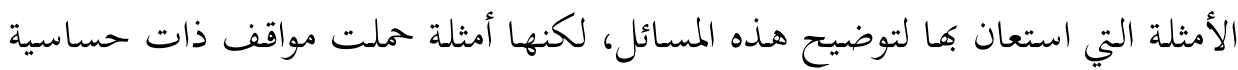
خاصة من الشريعة ومن التاريخ الإسلامي؛ ولعلَّ هذا مكمن أهمية النظر في هذه المسألة. وليس القصد كذلك إظهار وجه غير فلسفي لأبي الوليد بن رشد، الذي كان ينظر

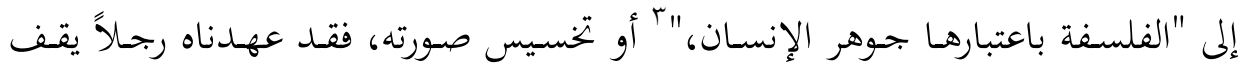

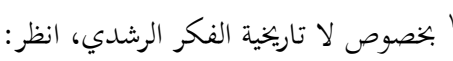

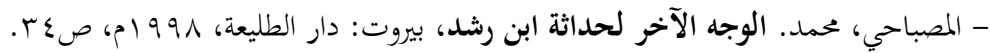

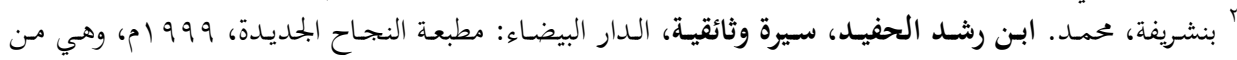

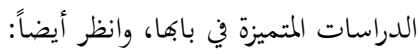

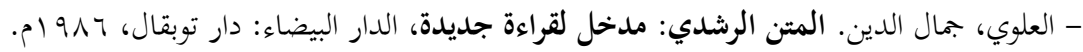

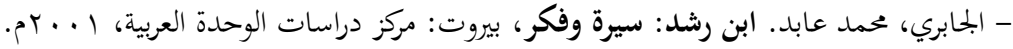

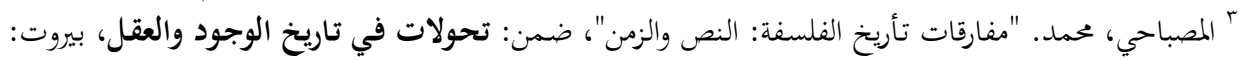

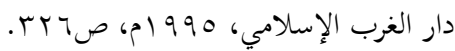


موقفاً عدلاً بين الأقوال، وإنما كان القصد تحديداً هو إثارة الانتباه إلى مواقف حضارية (دينية وسياسية)، لم يكن له بدّ مـن تسجيلها؛ انطلاقاً مـن تفاعله مع سياقه التاريخي

والحضاري.

\section{أولاً: مواقف دينية}

\section{ا ـ القرآن وباقي الكتب السماوية:}

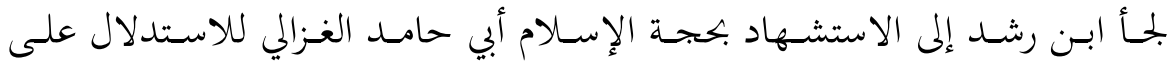

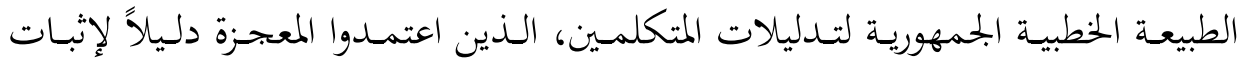

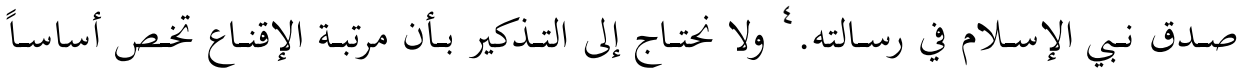

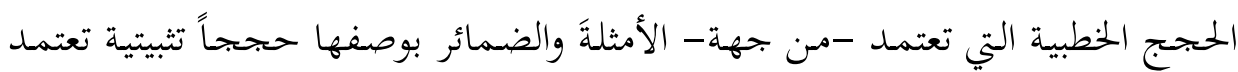

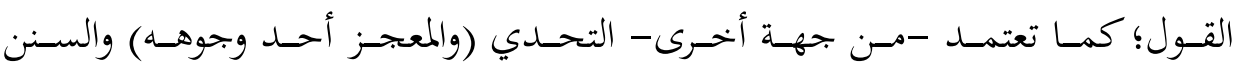
والشهادات... بوصفها حججاً تثبيتية غير قولية أو غير صناعية.

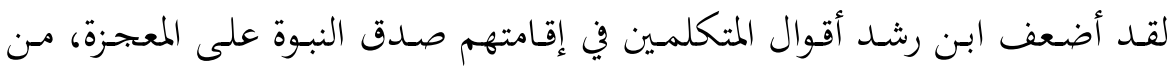

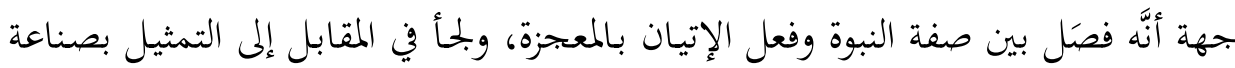

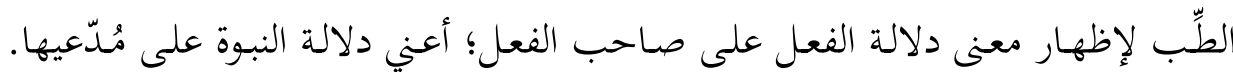

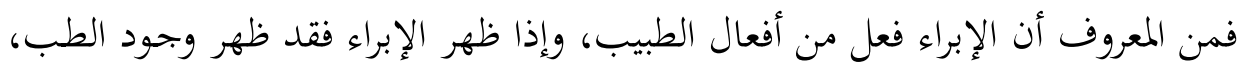

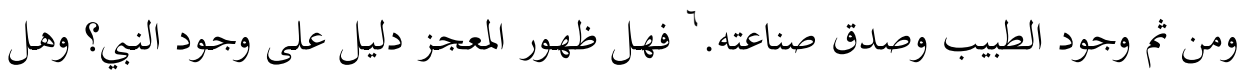
" يقول: "وقد صرح أبو حامد في كتابه الملقب بالقسطاس بهذا، وقال: "الإيمان بالرسل بطريق المعجز على ما رسمه

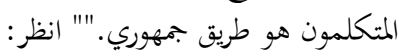
- ابن رشد، أبو الوليد محمد بن أممد. مختصر كتاب الخطابة، تحقيق: تشارلز بتروورث، ص79 1، نشر (باسم

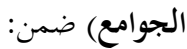

- Averroes, Three Short Commentaries on Aristotle's "Topics", "Rhetoric", and "Poetics", New York: Albany State University of New York Press, 1977.

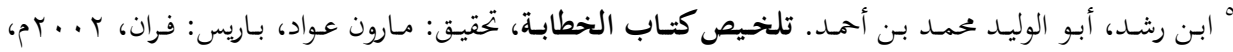

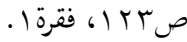
" ابن رشد، أبو الوليد محمد بن أحمد. الكشف عهد عن مناهج الأدلة في عقائد الملة، تحقيق: مصطفى حنفي، بيروت:

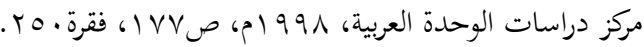




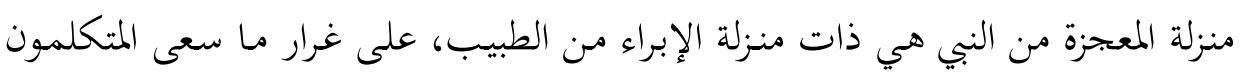

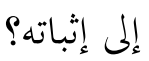

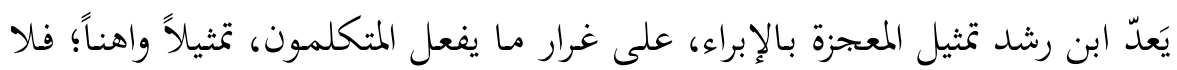

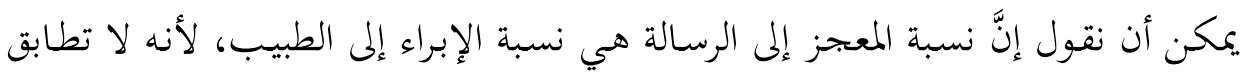

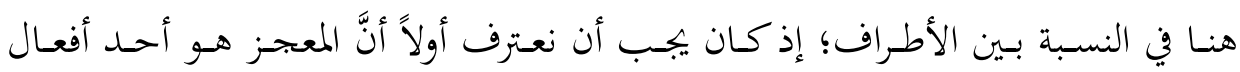

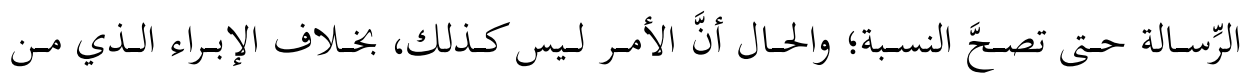

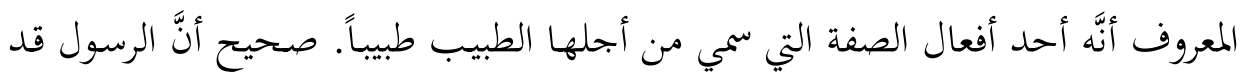

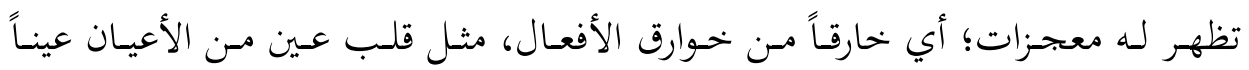

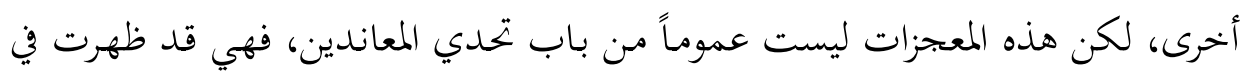

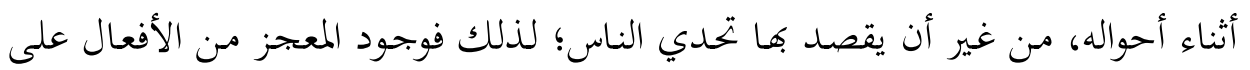

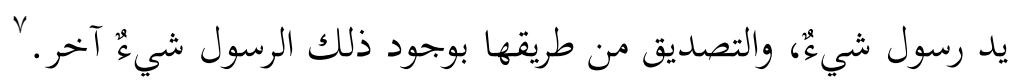

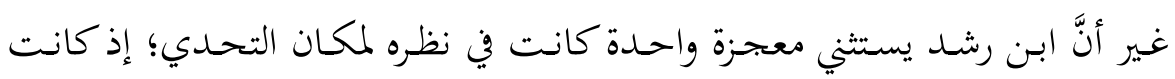

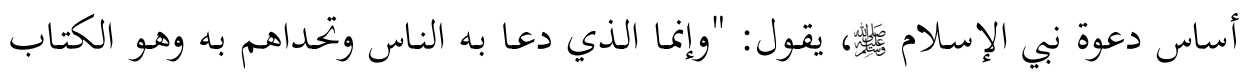

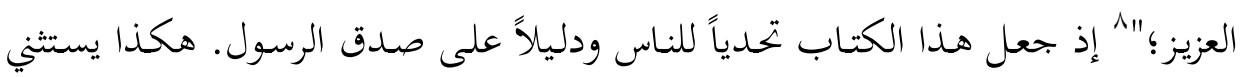

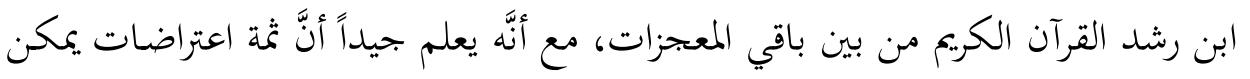

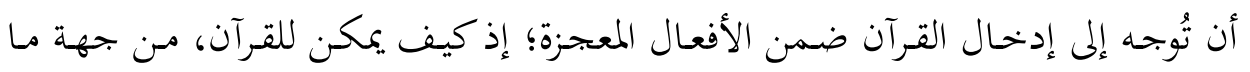

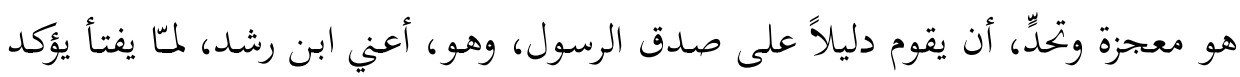

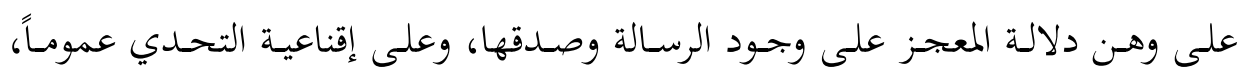

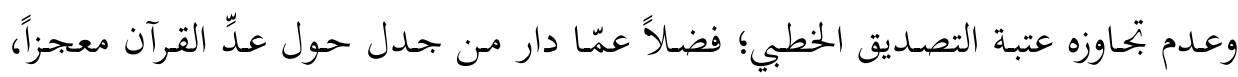

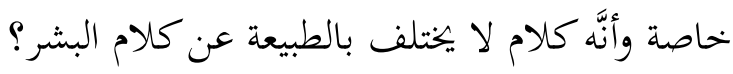

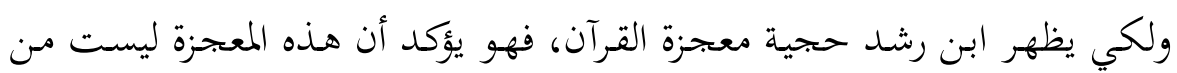

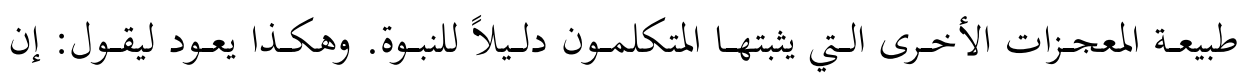

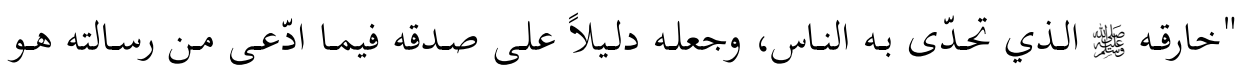
" لنعاج هذه المسألة في دراسة منفردة تصدر عن بجلة كلية الآداب بالرباط.

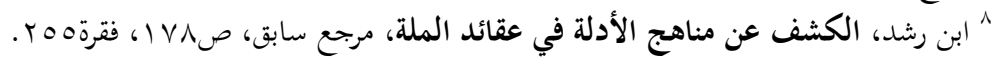




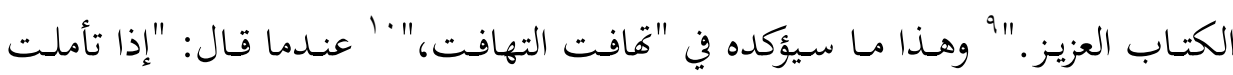

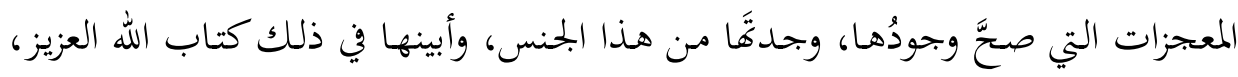
الذي لم يكن كونه خارقاً من طريق السماع كانقلاب العصا حية، وإنما ثبت كونه معجزاً

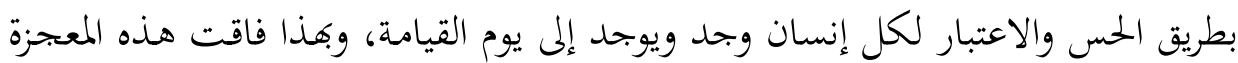

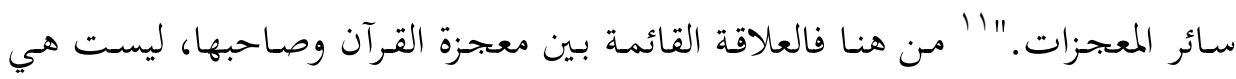

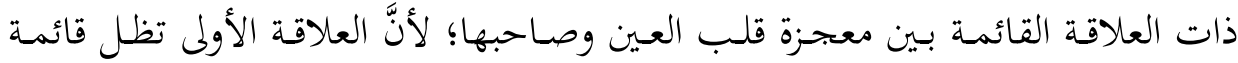

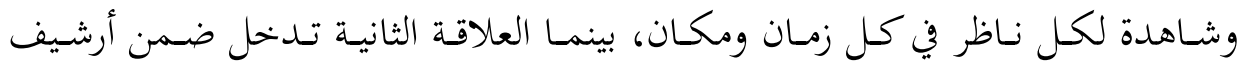
التاريخ؛ إذ لا يكون للمتأخر من طريق للتصديق بها سوى طريق السماع. ومـن هنا تَميز

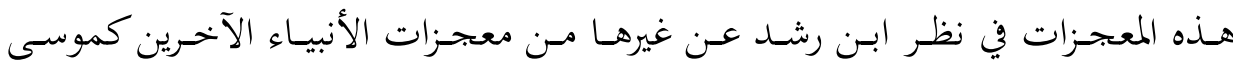

ولكي يقف ابن رشـد على معنى صدق نبي الإسـام سلك طريق مقايسة شريعة

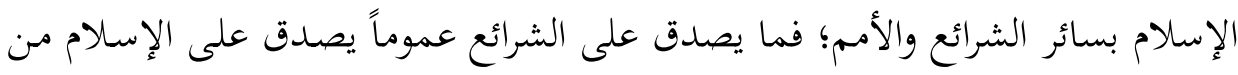
باب الأولى. وهكذا يحتجُُ بقياس الأولى مـن خهلال مقارنة القرآن مع الكتـب السماوية الأخـرى (التوراة والإنجيـل)، فيقـول: و "بالجملـة فـإن كانـت هاهنـا كتـب واردة في شـائع

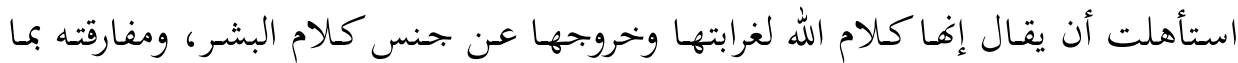

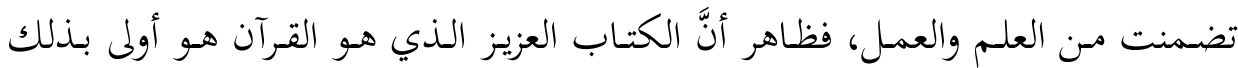

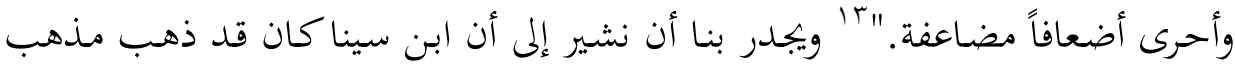
ابن رشد نفسه في هذه المسألة؛ إذ يقول في إثبات النبوة المحمدية: "وأما صحة نبوة نبينا

10 Leaman, Oliver. Averroes and His Philosophy, Oxford: Oxford University Press, 1988, p. 53.

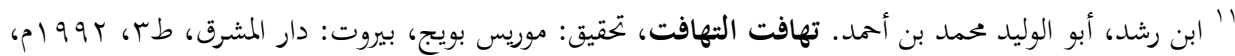
.0170 "ايجدر بنا أن نشير إلى أن الفيلسوف الأندلسي موسى بن ميمون، المعاصر لابن رشد، قد ذهب في كتابه "دلالة

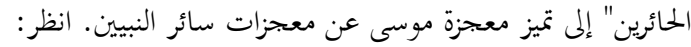

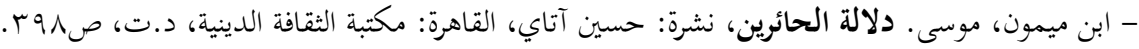

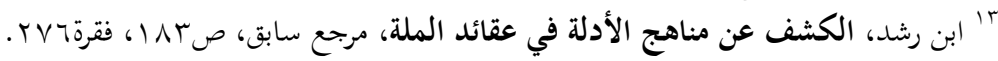




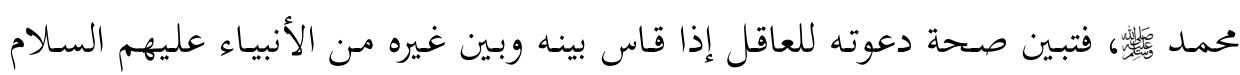

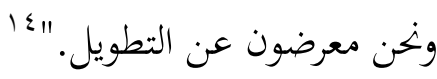

وتظهر المقايسة الثانية التي نقف مـن خلالهـا على صددق النبوة في تمثيل ابن رشـد

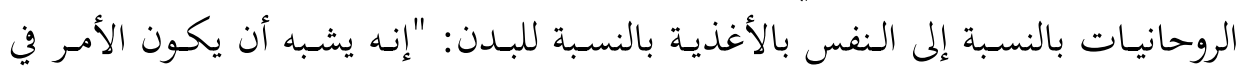

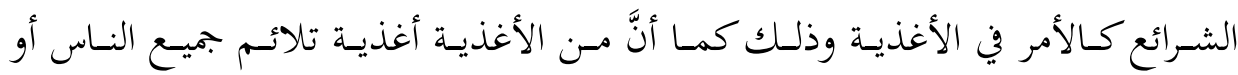

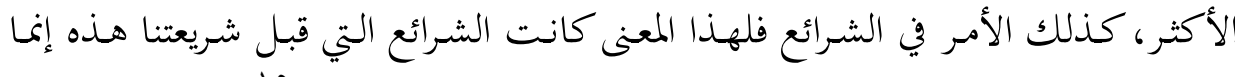

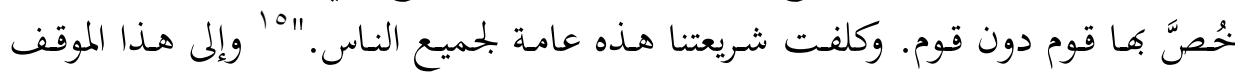

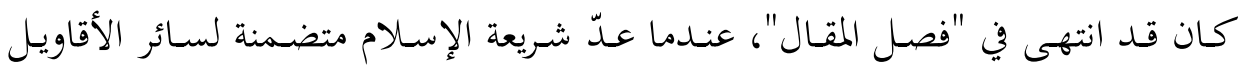

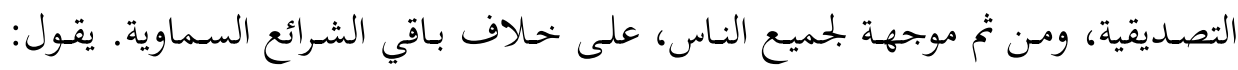

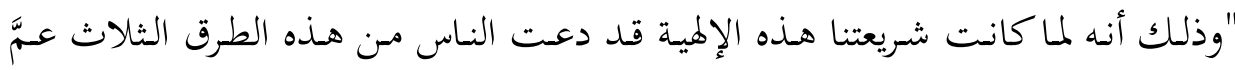

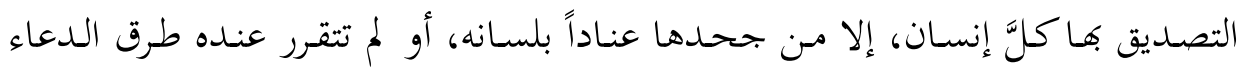

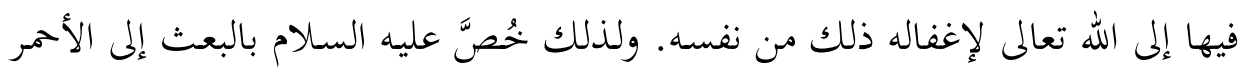

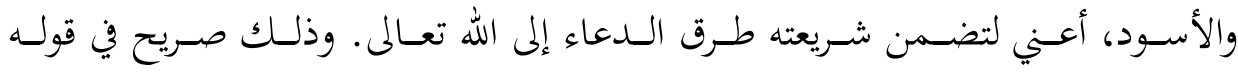

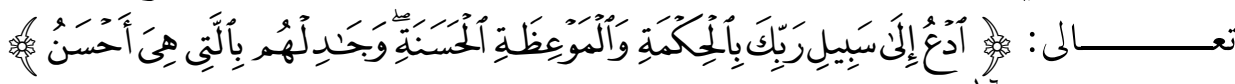

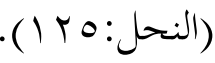

مـن هنـا فإِنَّ شريعة الإسـام في نظر ابن رشـد أولى بالتصديق وأحسرى مـن غيرهـا.

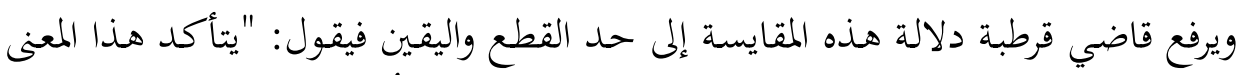

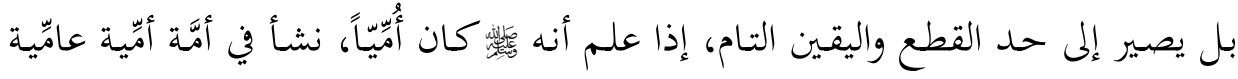

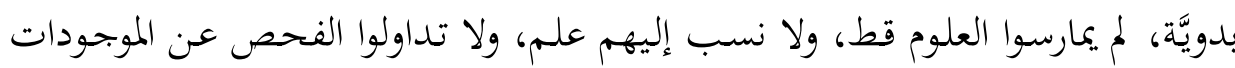

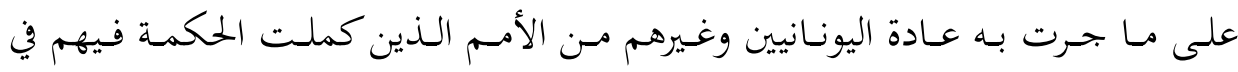

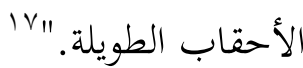

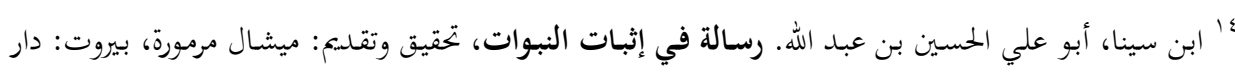

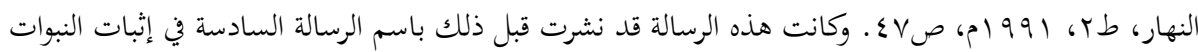

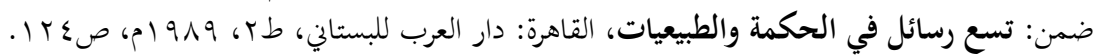

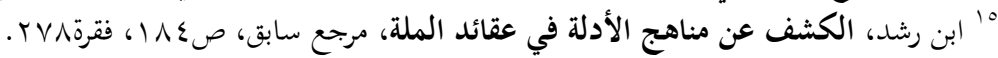

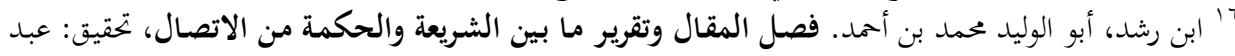

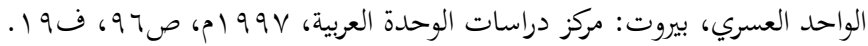

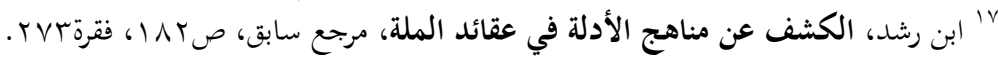




\section{Y. التمثيل علة تفاضل الثرائع:}

لم يلجأ الشرع، حسب ابن رشد، في تعريف الجمهور بالموجودات وبالصانع إلى إلى

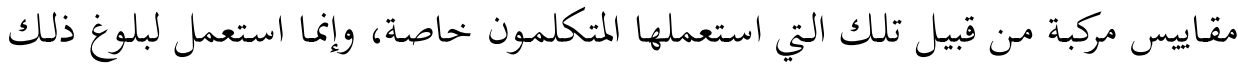
المقصدِ الشريفِ طريق التمثيل بما هو طريق قريب بسيط. وبالنسبة لابن رشد فآي القرآن

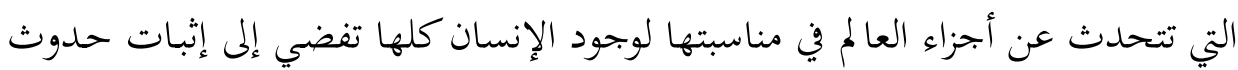

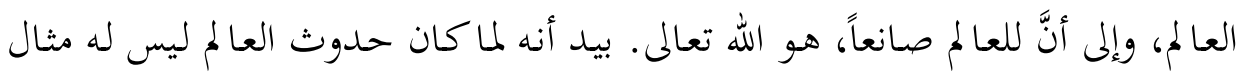

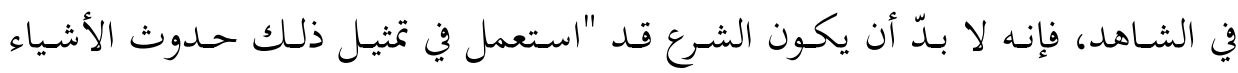

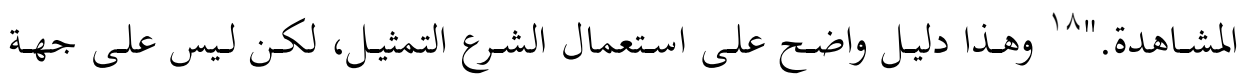

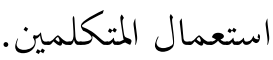

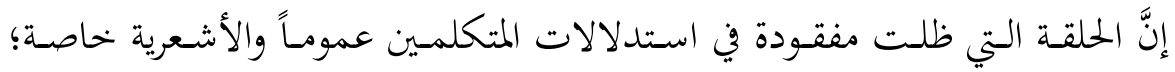

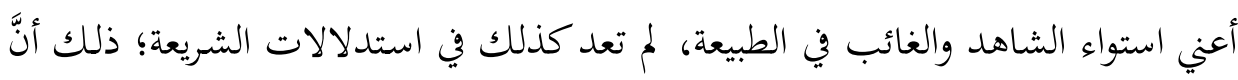

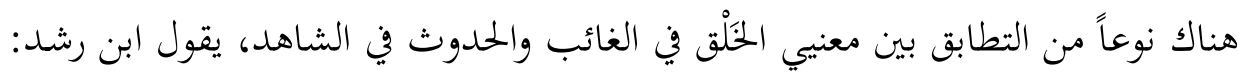

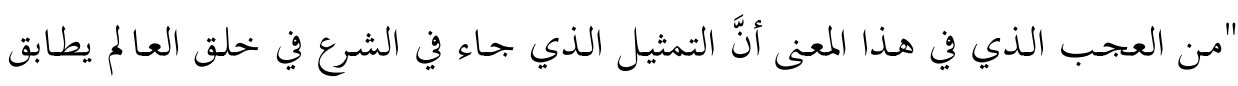

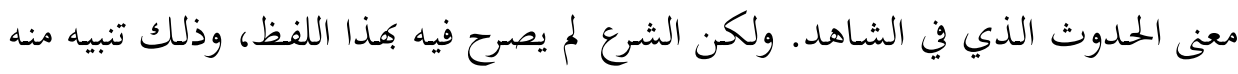

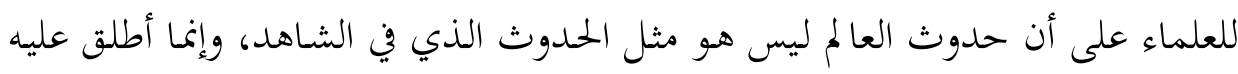

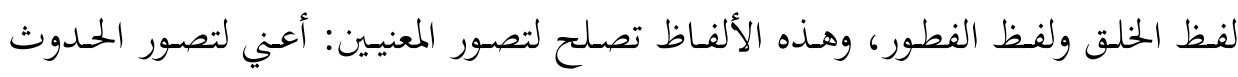

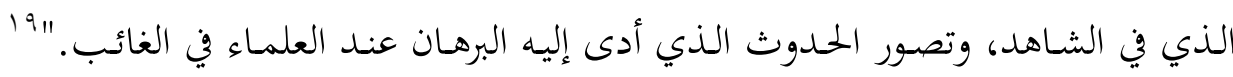

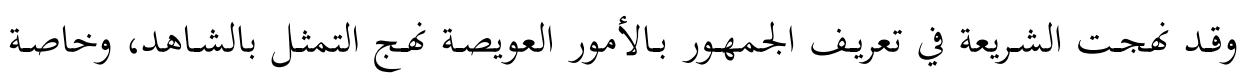

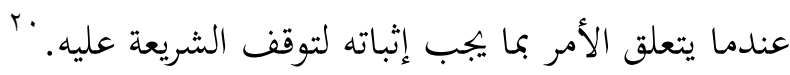

وبالفعل، ف"الطريق التي سلك بالجمهور في تصور هذا المعنى فهو التمثيل بالشاهد،

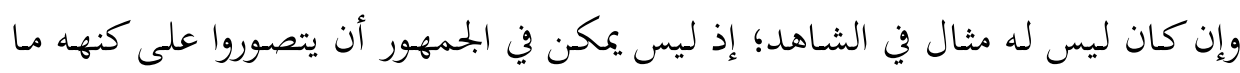

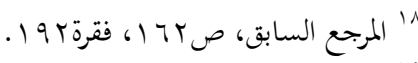

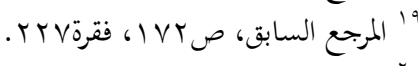

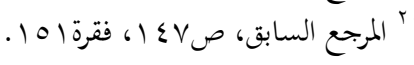




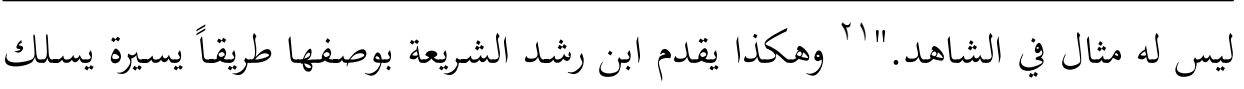
فيها بالجمهور نحو ما قصد أن يعتقده الجمهور؛ أي "معرفة الطريق التي تفضي إلى وجود

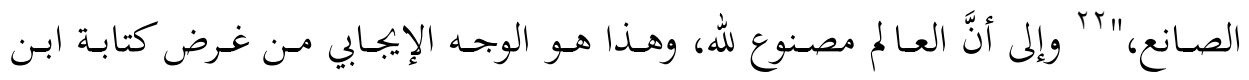

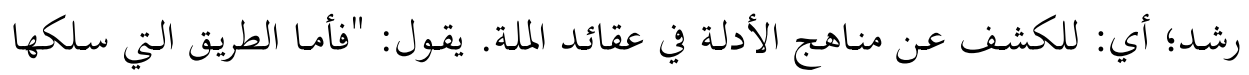

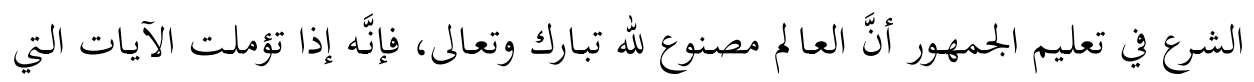
تضمنت هذا المعنى، وجدت تلك الطرق هي طريق العناية. وهي إحدى الطرق التي قلنا

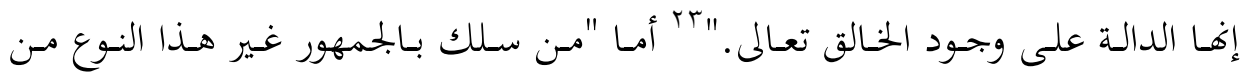

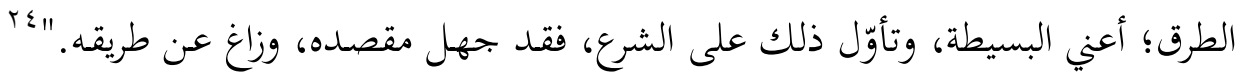

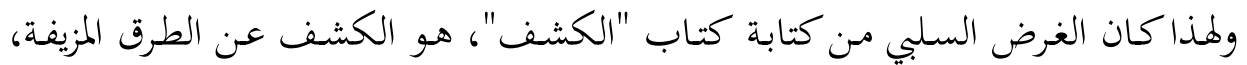
التي تزيغ بسالكيها عن المقصد الأساس من الشرع؛ وهذه هي طرق المتكلمين في نظره. هكذا يكون قد تبين أنَّ هذه الطريقة الشرعية التي نصبها الشرع للجمهور ليعرفوا

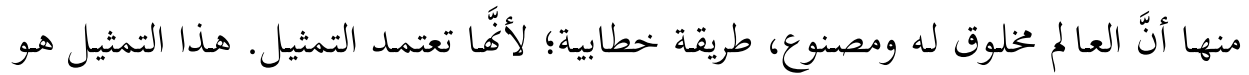

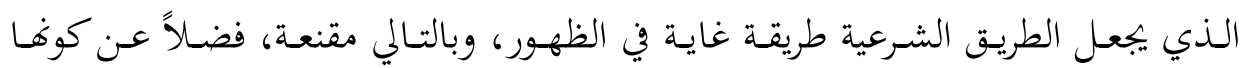

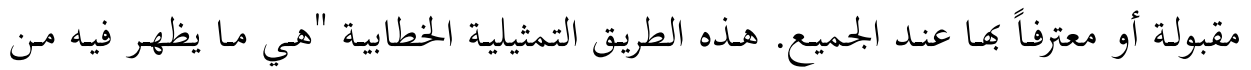

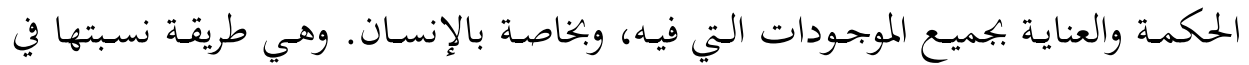

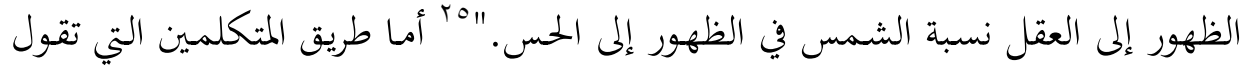

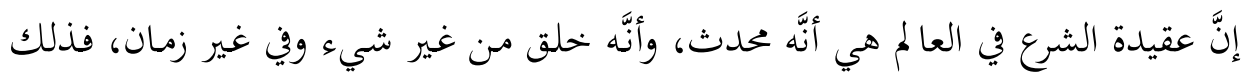

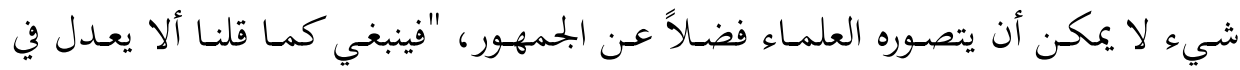

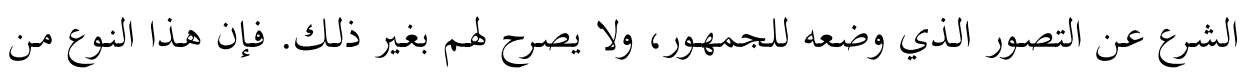

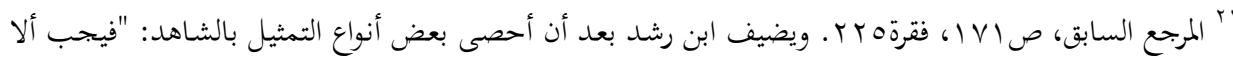

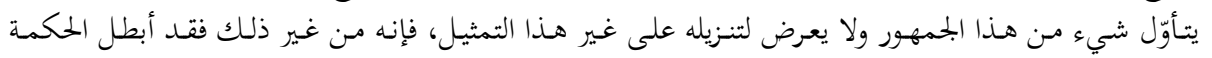


التمثيل في خلق العالم هو الموجود في القرآن وفي التوراة وفي سائر الكتب المنزلة،" "جابل بل

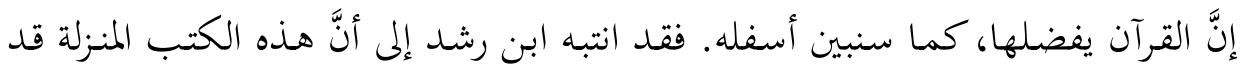

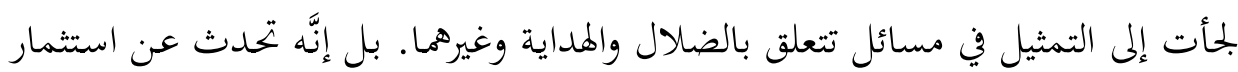
الشريعة المحمديـة لاستعارتي النور والشمس والتمثيل بهما في مسـائل عقدية دقيقـة، كمـا تحدث عن تميز هذه الشريعة عن باقي الشرائع في استثمار هذه التمثيلات التي هي "أتم

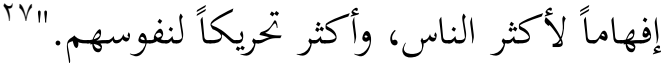

لا خحلاف إذن في لجوء سائر الكتب المنزلة إلى استعمال آليات التمثيل والاستعارة

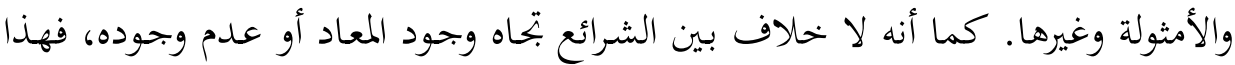

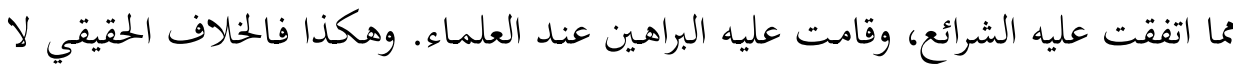
في وجود المعاد، ولا في صفة وجوده، وإنما في طريقة التمثيل له، التي فجتها الشرائع في

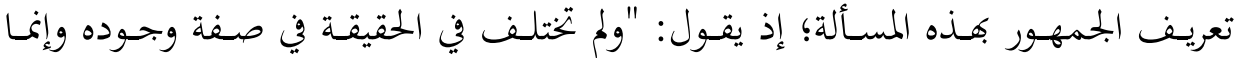

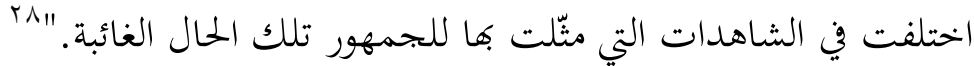

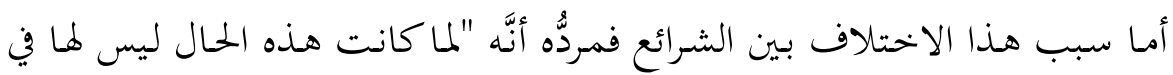
الشاهد مثال، وكان مقدار ما يدرك بالوحي منها يختلف في حق نبي نبي لتفاوقم في هذا

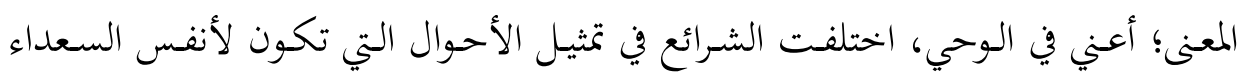

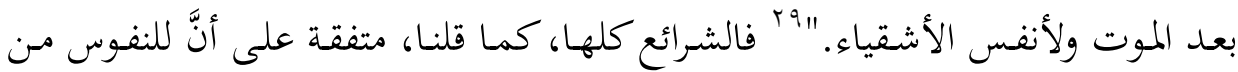

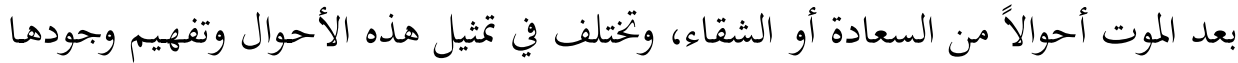

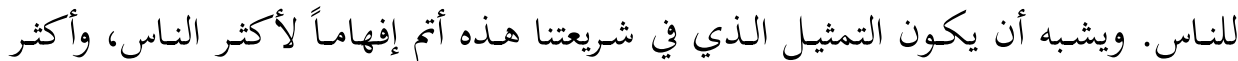

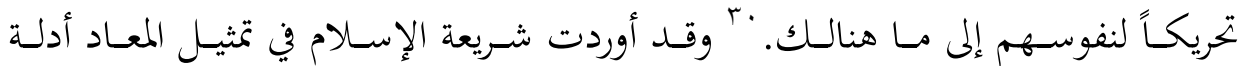

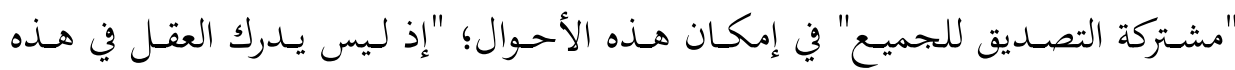

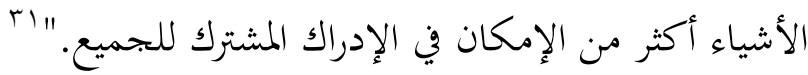

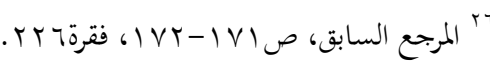

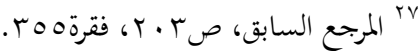

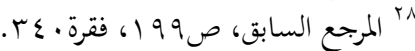

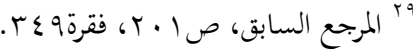

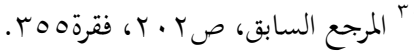

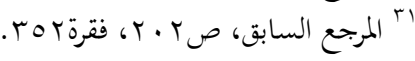


ويقسّم ابن رشد التمثيل إلى: تمثيل روحاني وآخر جسماني؛ إذ يقول عن خصائص

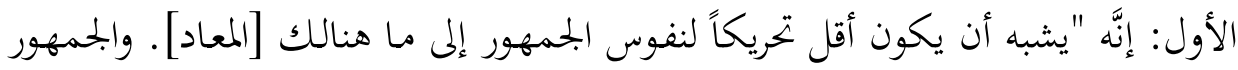

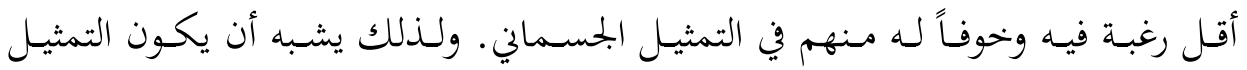

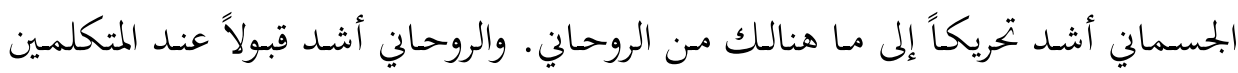

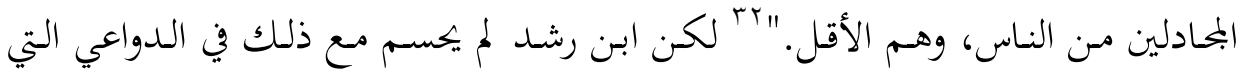

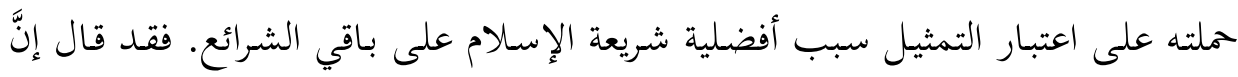

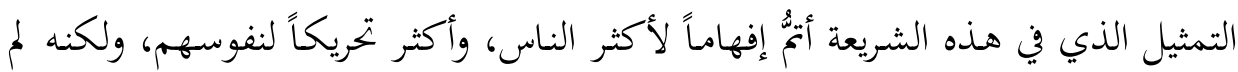

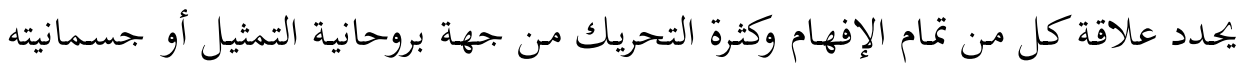

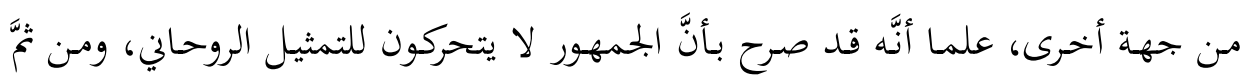

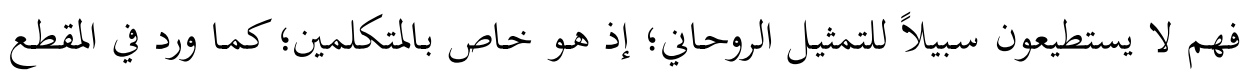
المستشهد به قبل قليل.

ها هنا يكون ابن رشد قد استوحى ما سبق أن أثبته في شروحه على كتاب "النفس" لأرسطو. وبيانه كما يلي:

إنَّ تمـام الإفهام وشـدة التحريـك يتعلقـان بطبيعـة التمثيل المستعمل أساسـاً. فكلمـا

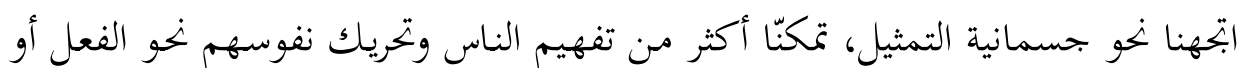

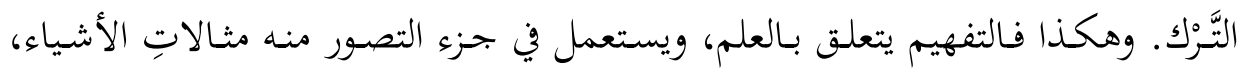

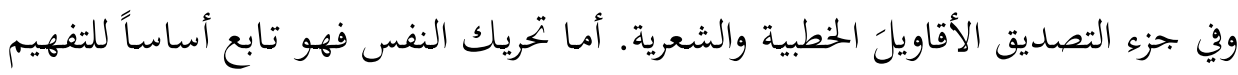

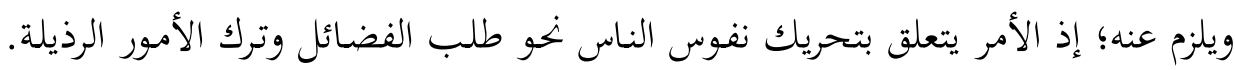

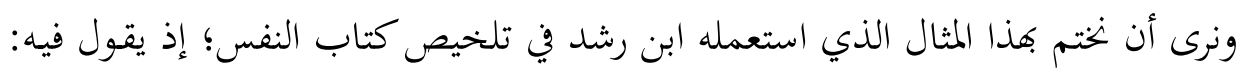

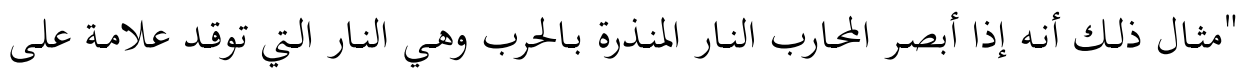

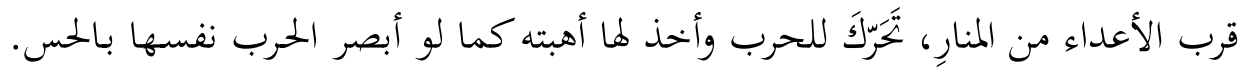

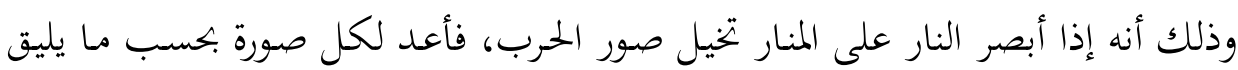

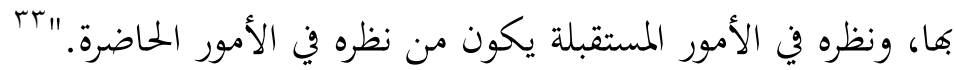

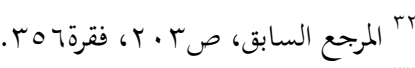

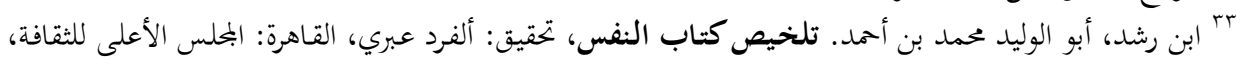


والحقيقة أن ابن رشد يترك الباب مفتوحاً ليعدد الأحوال التي فهم بها أهل الإسلام

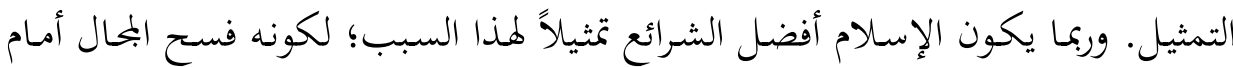

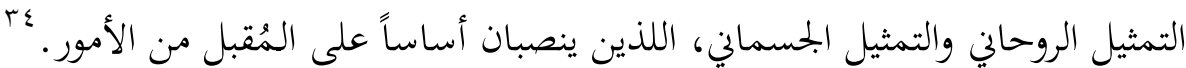
نخلص مما سبق أنه بقدر ما تكشف مواقف ابن رشد هذه على نوع من التفضيل

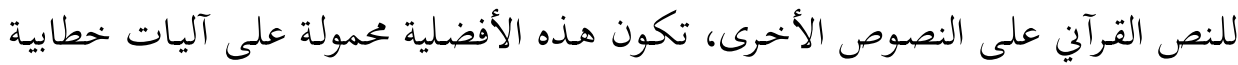

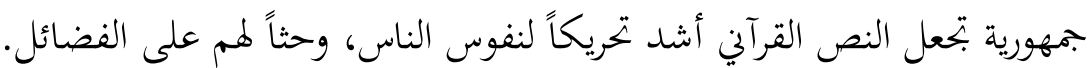

\section{ب. استعمال تاريخ الخلافة الإسلامية:}

تعرض ابـن رشـد لتعريف الاستدلال التمثيلي في عـدة مؤلفـات، مـن بينها تخليص كتاب القياس. وكتاب القياس أو التحليلات الأولى، كما يعرف الباحثون، مؤلف تقني عرض فيه أرسطو أنواع الأقيسة والفروق بينها. وفي نظر مققي هذا النص ودارسيه، فقد كان تلخيص ابن رشد لصيقاً بالنص الأصلي. لكن هذا الاقتراب تخللته بعض المواضع

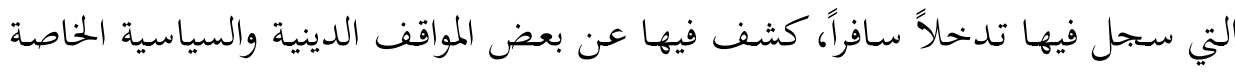
بحضارته وبتاريخه. وفي هذا السياق كان الدارس (استيفان هاريف)Steven Harvey قد كشف في إحدى مقالاته عن الخلفيات العقدية التي وجهـت ابن رشد في تلخيصه لهذا

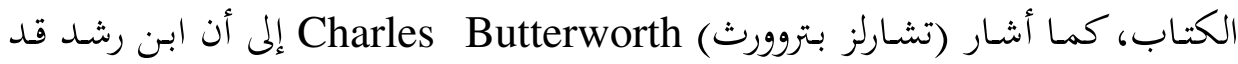
اغتنم فرصة شروحه على بعض نصوص أرسطو المنطقية ليضمنها بحموعة مـ الرسائل

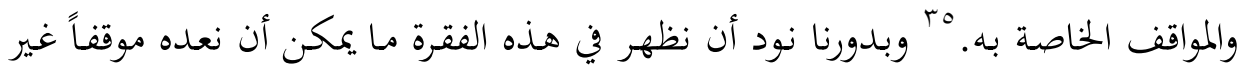
مكتمل من الخلافة الإسلامية ومن قتل الخلفاء.

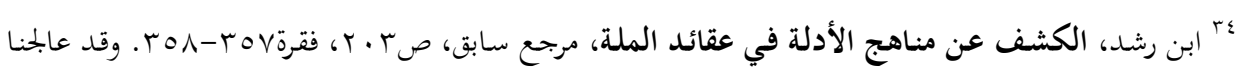

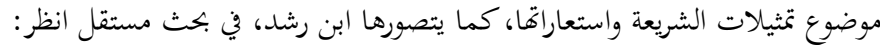

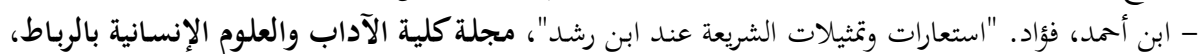

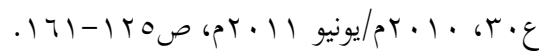
${ }^{35}$ Harvey, Steven. 'Averroes' Use of Examples in His Middle Commentary on the Prior Analytics, and some Remarks on His Role as Commentator', Arabic science and philosophy, vol.7, 1997.

وانظر المقدمة التي وضعها تشارلز بتروورث لـ"جوامع ابن رشد المنطقية". 
يتطرق ابن رشد، في معرض تحديده للمثال للفرق بينه وبين الاستقراء. فالاستقراء

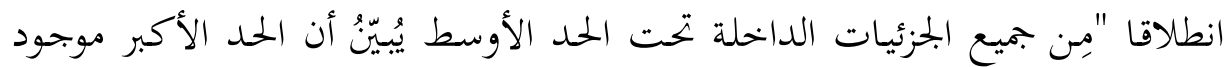

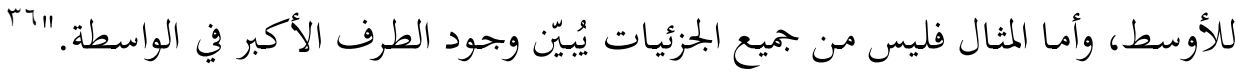

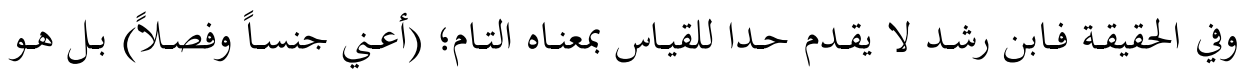
على الأصح يقدم لنا وصفاً لجهة استعمال المثال. يقول: "أما المثال فهو أن يُبيّن وجود الطرف الأكبر في الأصغر، بأن يُبيّن وجود الأكبر في الأوسط بوجود الأكبر في الشبيه بالأصغر، إذا كان وجود الأوسط في الأصغر والأكبر في الشبيه بالطرف الأصغر أبين من الأن

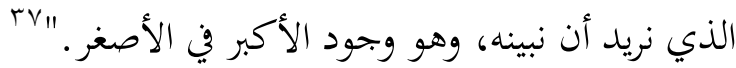
ولأجل توضيح جهة اشتغال المثال، يورد ابن رشد الاستدلال التالي:

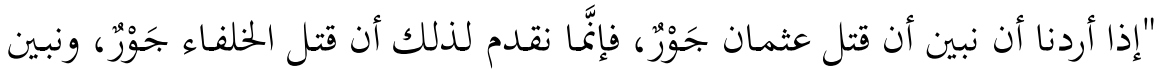

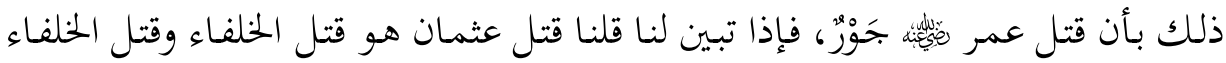

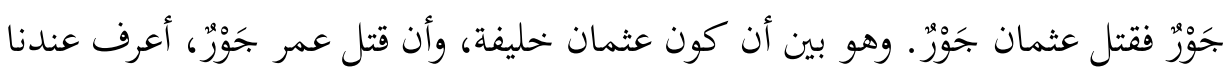

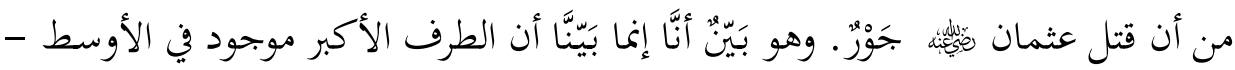

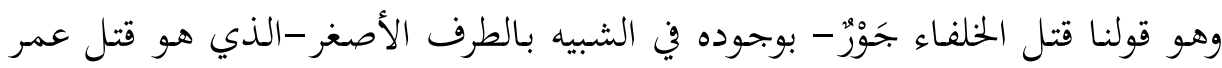

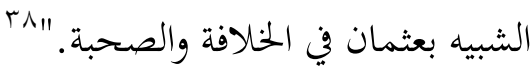

إن اختيار ابن رشد لهذا المثال "قتل الخنفاء"، وهو طبعاً غير المثال الذي استعمل

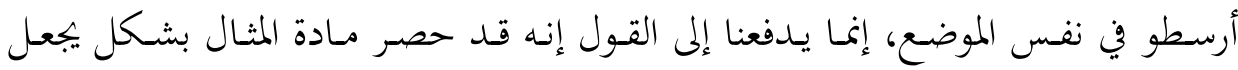

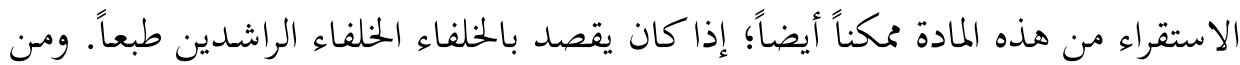

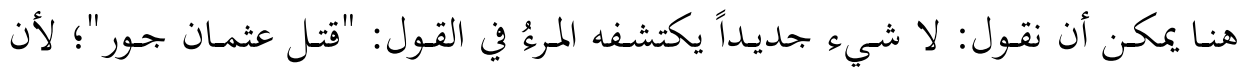

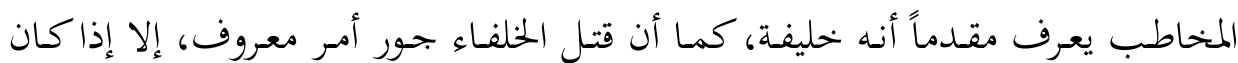

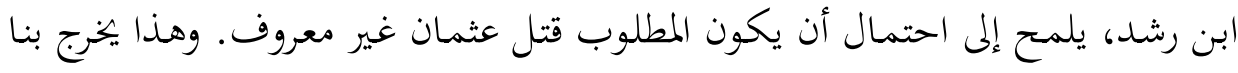

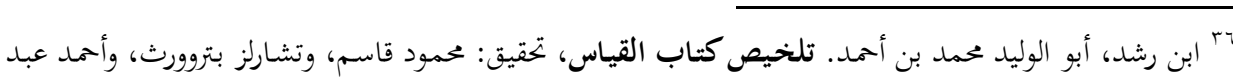

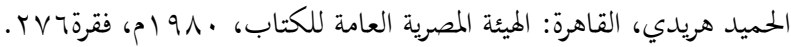

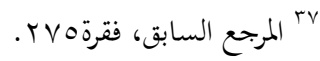

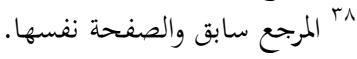




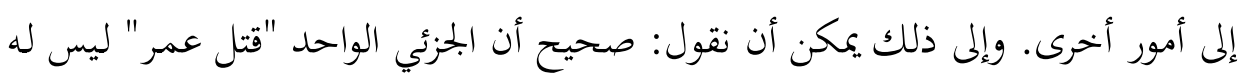

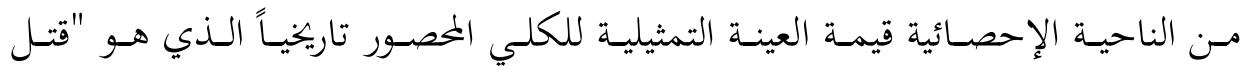

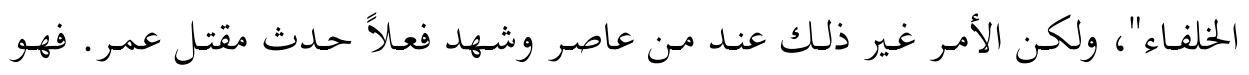

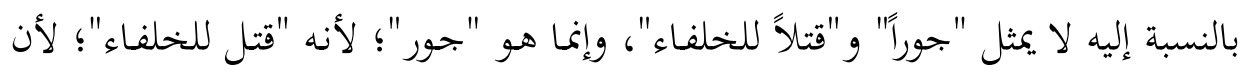
العلاقة بين "الجور" و "قتل الخلفاء" علاقة علية.

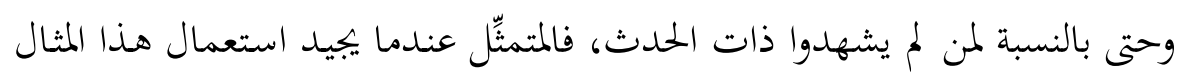

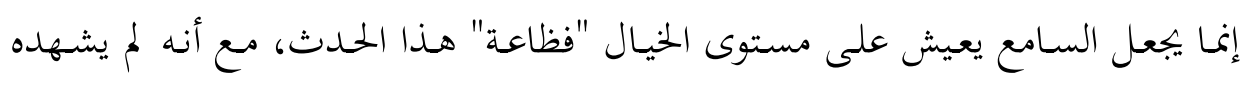

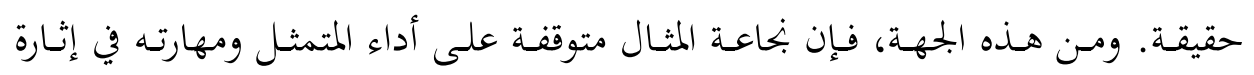

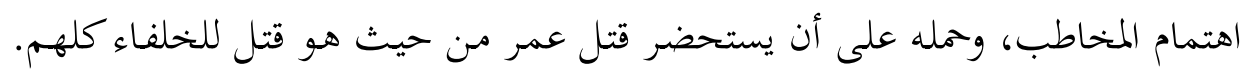

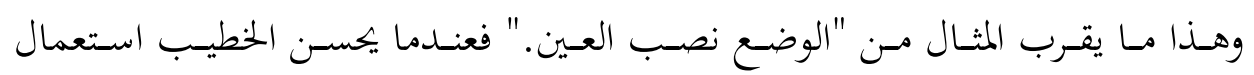

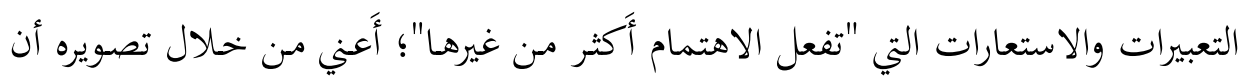

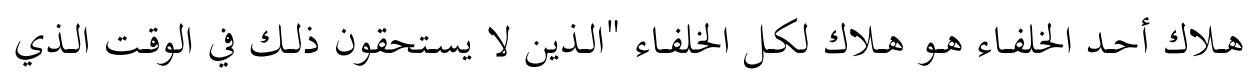

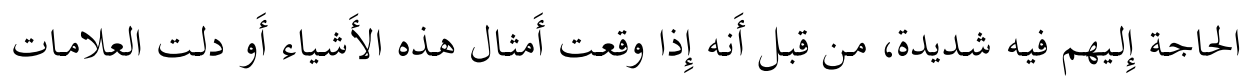

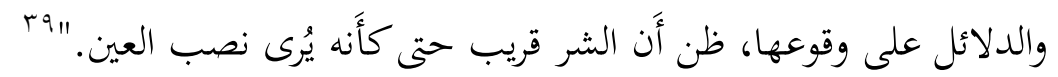

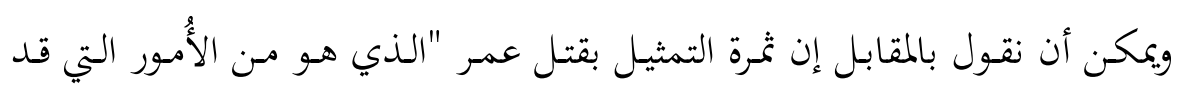

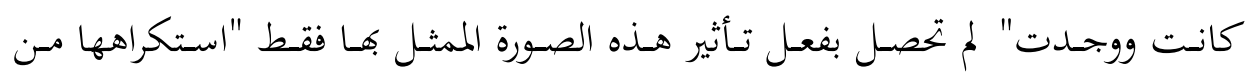

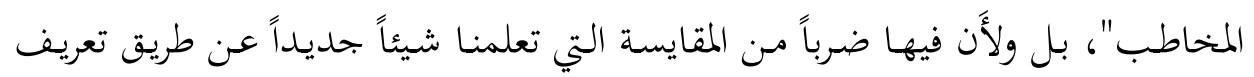

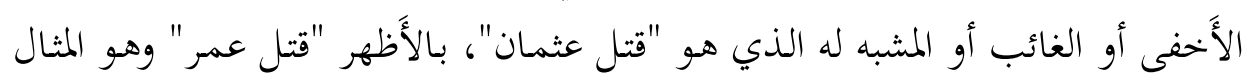

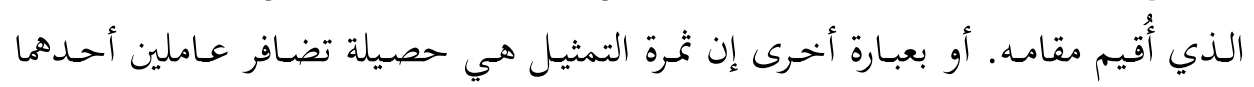

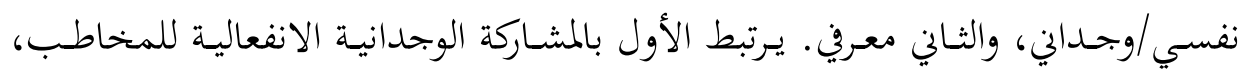

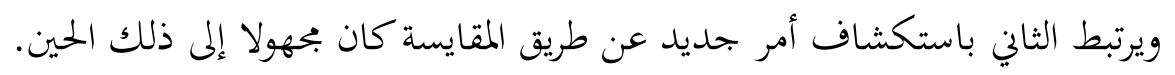
ومن هنا يظهر أن ابن رشد كان يشرح نصوص أرسطو بذهن يحمل موروثات فكرية

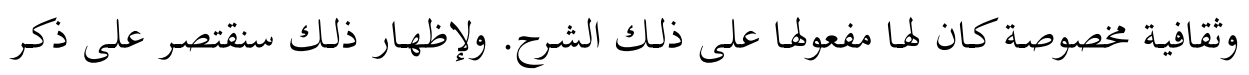
9r ابن رشد، تلخيص كتاب الخطابة، مرجع سابق، ص 9 1 -19 1 ، فقرةV |. 


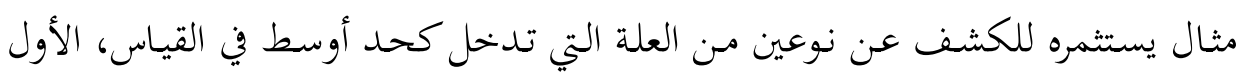

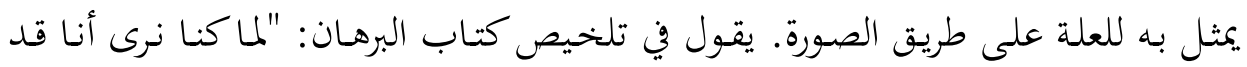

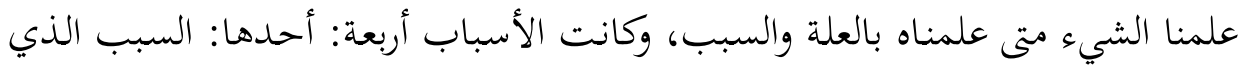

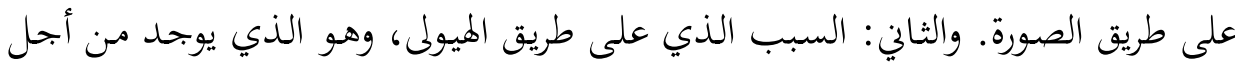

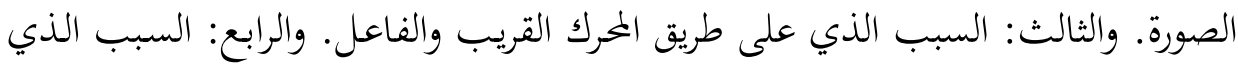

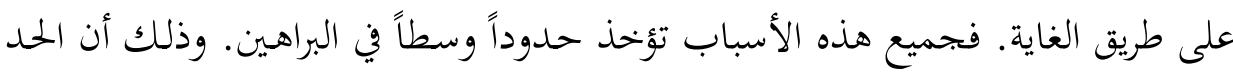

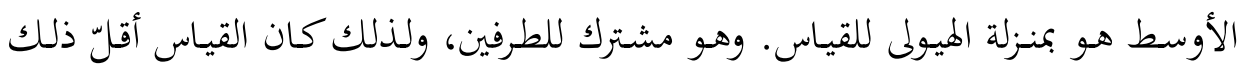

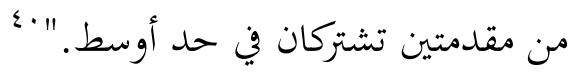

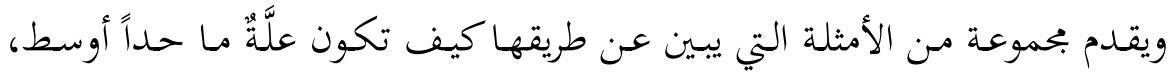

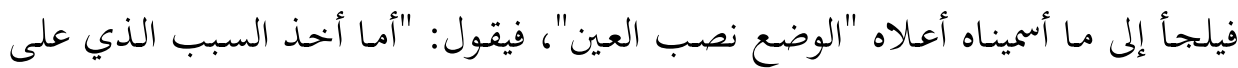

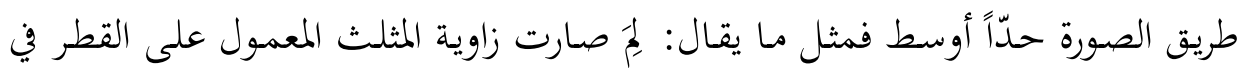
نصنف الدائرة قائمة؟ فيقال: لأهما نصف الزاوية التي على المركز والزاوية التي على المركز

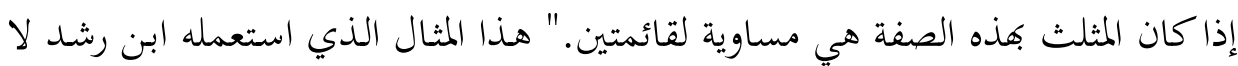

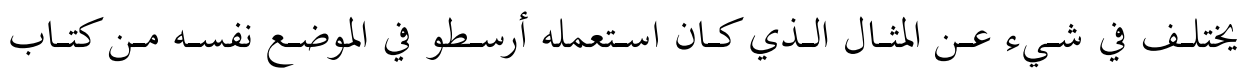

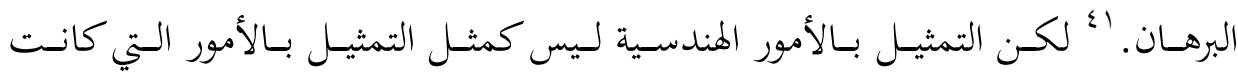

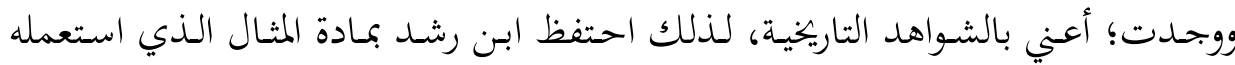

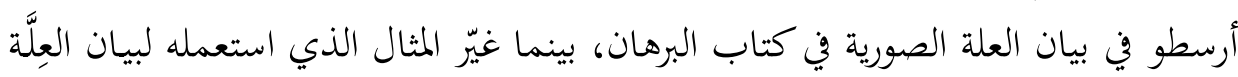

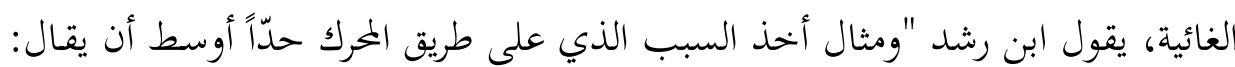

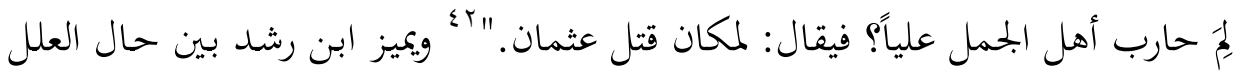

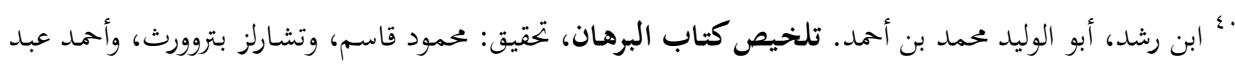

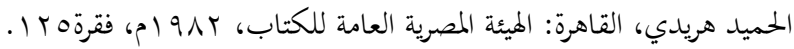

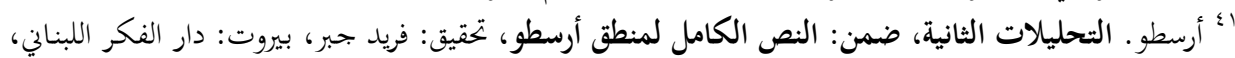
$.011-01 \cdot 0$. 1999

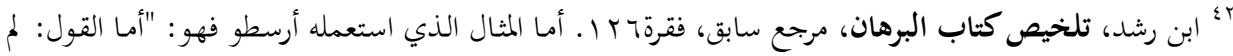

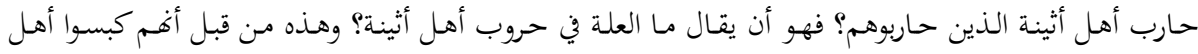

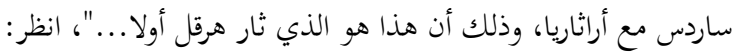

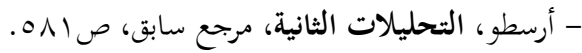


التي على طريق الغاية بالنسبة من معلولاتها، وحال العلل التي على طريق الفاعل بالنسبة إلى معلولاهّا، لكن هذا التمييز مؤسس عنده على على عامل التقدم بالزمن، "ذلك أك أن العلل

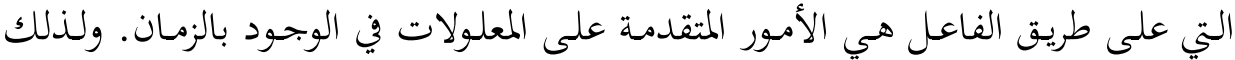

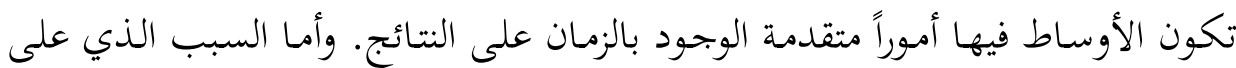

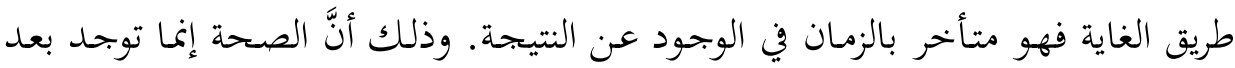

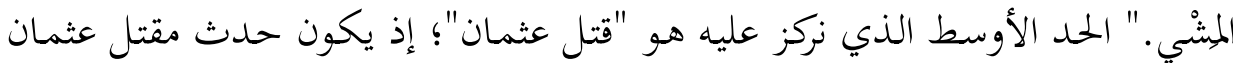

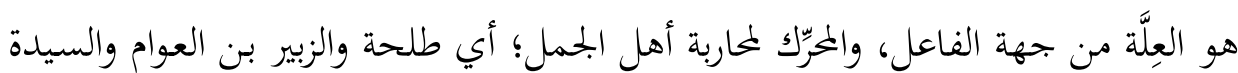

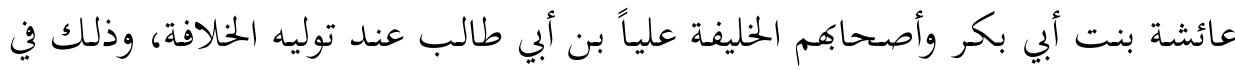

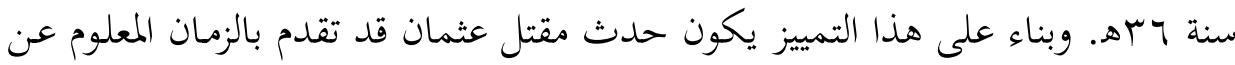
الحدث الذي هو محاربة علي.

هكذا يلجأ ابن رشد إلى هذا المثال مـ أجل إظهار دخول الحـد الأوسط علةً في

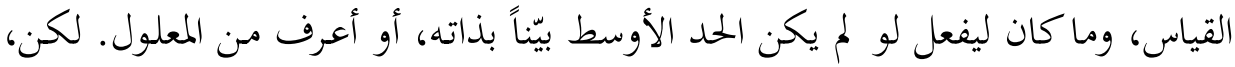

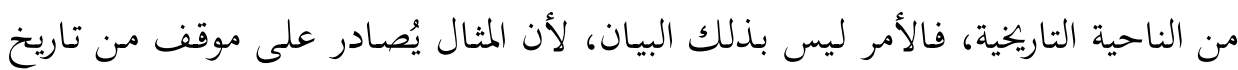

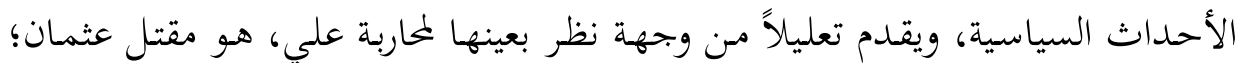

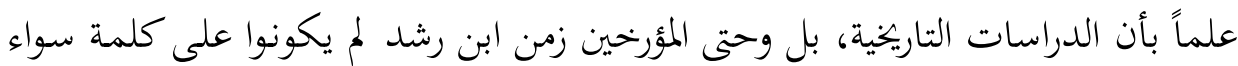
بخصوص هذه المسألة؛ أي مسألة ربط ذلك المعلول بتلك العلة بالذات.

\section{ثانياً: مواقف سياسية واجتماعية}

\section{I التاريخ السياسي بين الإلفاء والاستعمال:}

كنـا قد درسنا في موضع آخهر أصـناف المثال، كمـا رتبها ابن رشـد وحـدّدها ومـاز بعضها عن بعض؛ وقد تبين هنالك أنَّ الصنف الأول من المثال؛ أي "الأمور التي كانت

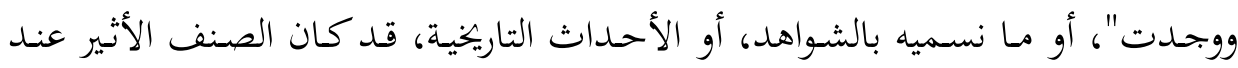

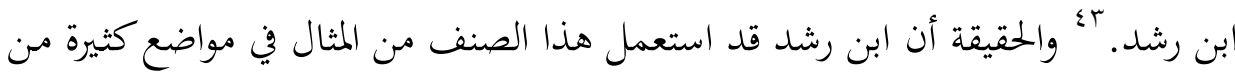

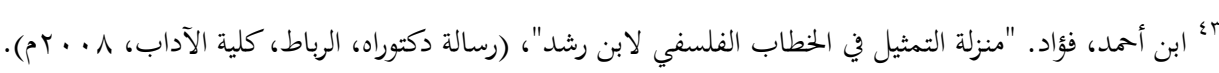


كتاباته، خاصة في الكتابات ذات المقصد العملي، على غرار "تلخيص كتاب السياسة"؛

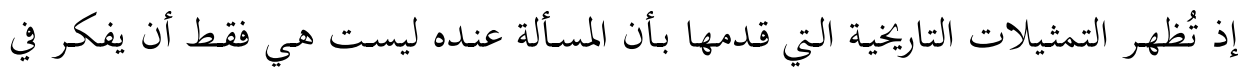

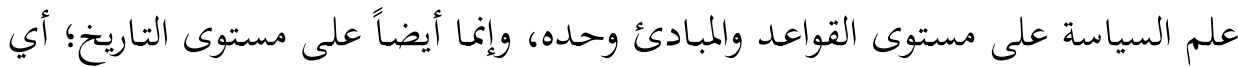

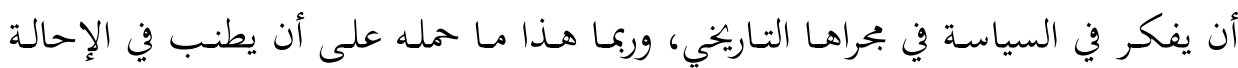

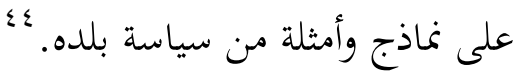
الصنف الأول من أصناف المثال هو "أَن يتمثل المتكلم بأُمور قد كانت ووجدلت"

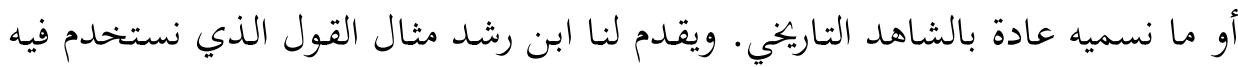

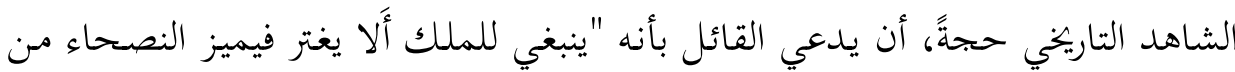

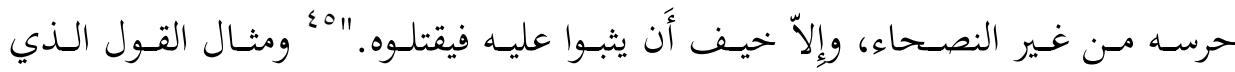

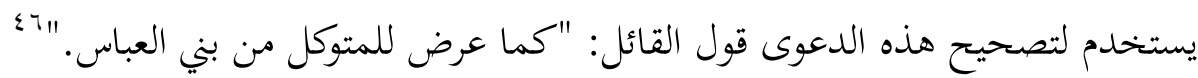
نستطيع أن نتحدث، انطلاقاً مـ كلام ابن رشد، عن بحموعة من الخصائص التي

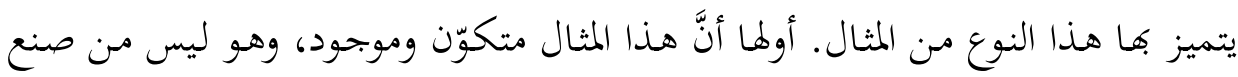

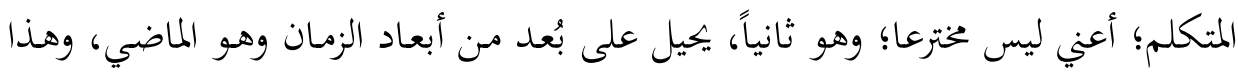

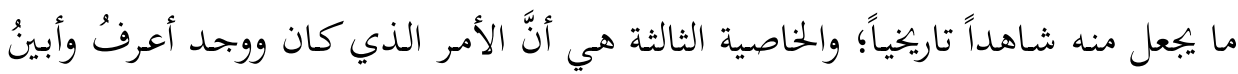

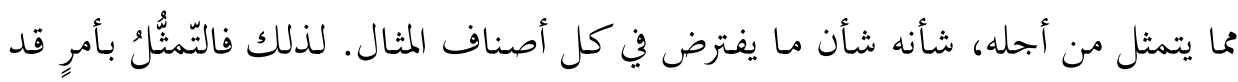

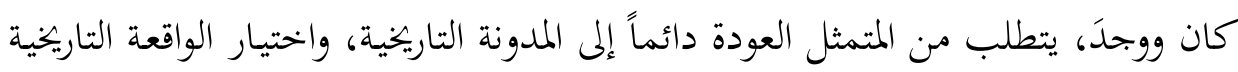

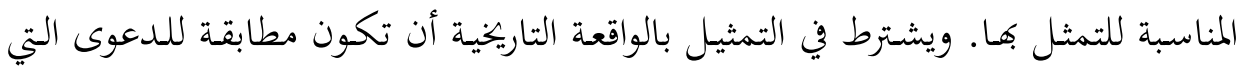

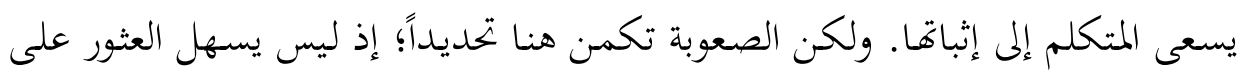

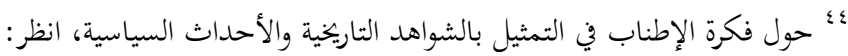

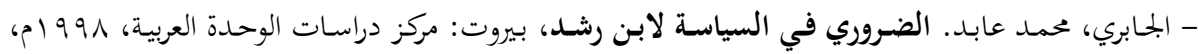

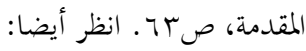

- Gerbier, Laurent. "La politique et la médecine: une figure platonicienne et sa relecture averroïste", Astérion [En ligne], 1 I 2003, mis en ligne le04 avril 2005, consulté le16 mars 2013.

URL: http://asterion.revues.org/13.

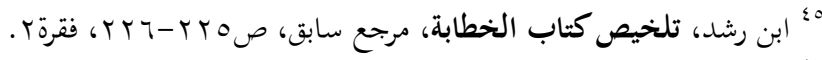
ب؛ المرجع السابق، والفقرة نفسها. 
وقـائع متطابقـة، أو بـالأحرى على واقعـة في الزمـان الماضـي مطابقـة للشيء الـذي فيـهـ الكامام.

وجداير بنـا أن نذكر هنـا أنَّ ابن رشد يختلف في تصور هذا الصنف من المثال عن

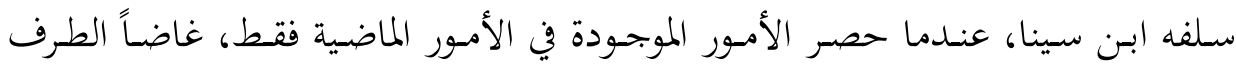

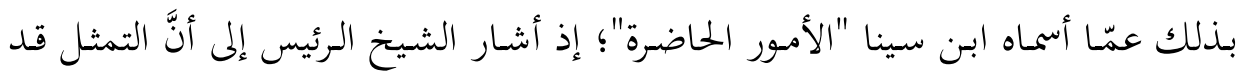

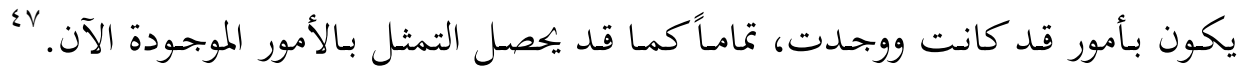

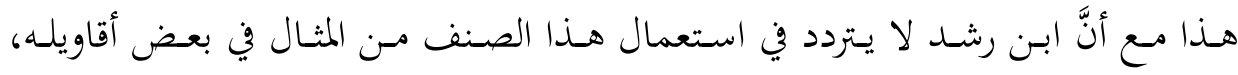

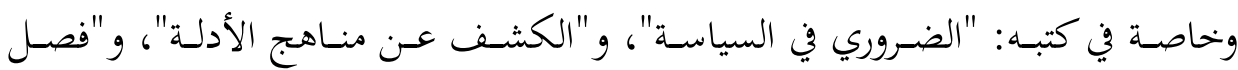

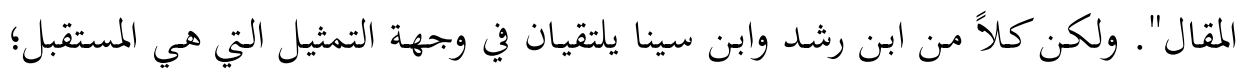

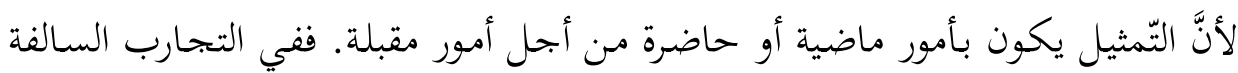
'عِلمُ مستأنف '، كما يعبّر الشيخ الرئيس. بداية، يظهر أنَّ الاستدلال الذي تمثل به ابن رشد هنا لاستعمال "الأمور التي قد

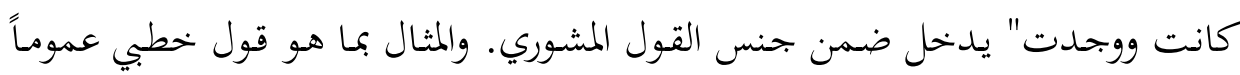

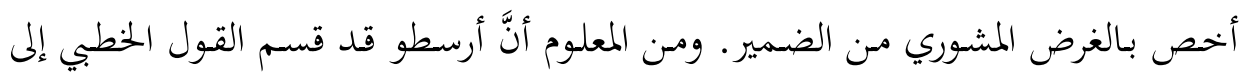

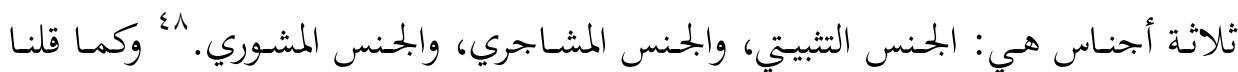

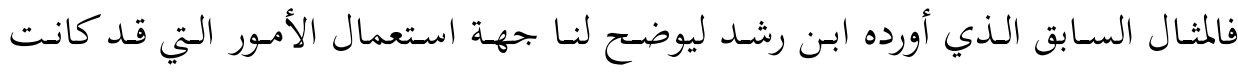

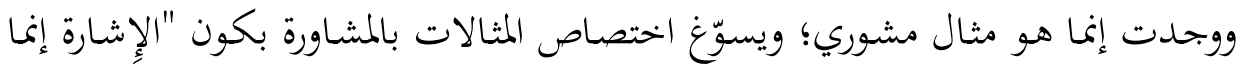

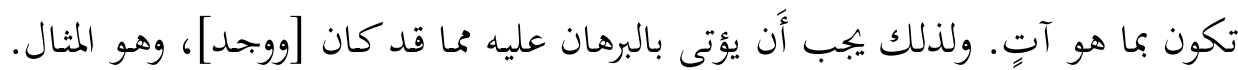

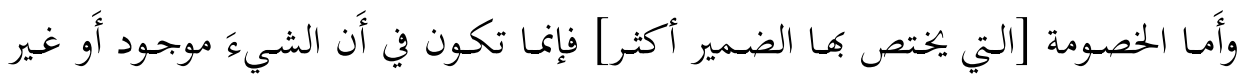

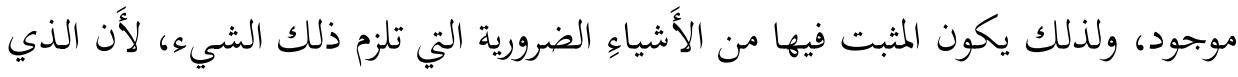

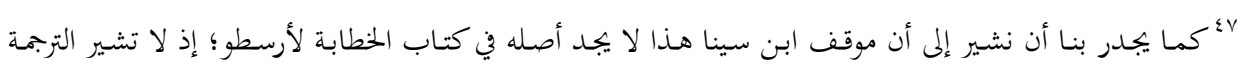

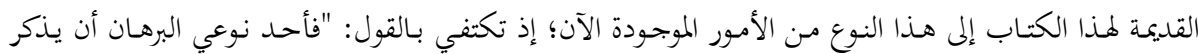

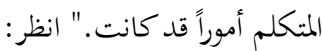

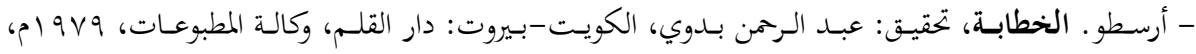
صVVIr 1.

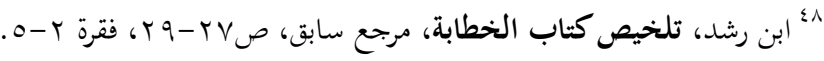


قـد كـان، لازمـه ضـروري الوجـود؛ أَي موجـود بالفعـل، لا ممكـن الوجـود. وأمـا الأمسور

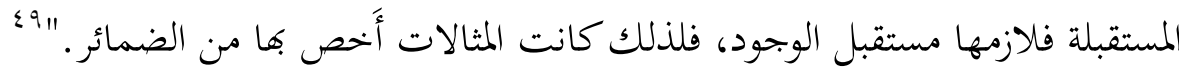
عندما ننظر في هذه الدعوى -"إنه ينبغي للملك أَلا يغتر فيميز النصحاء مـ حرسه

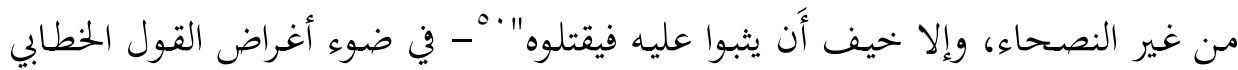

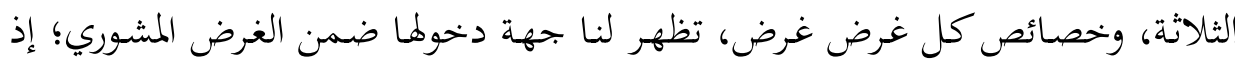

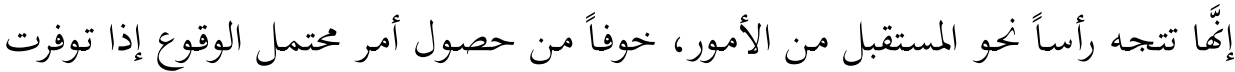

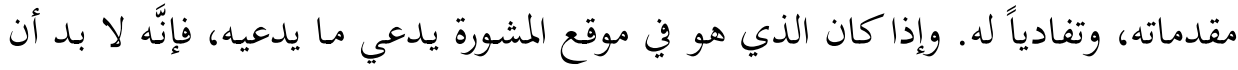

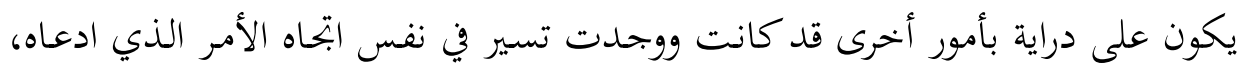

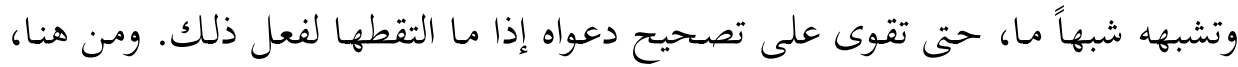

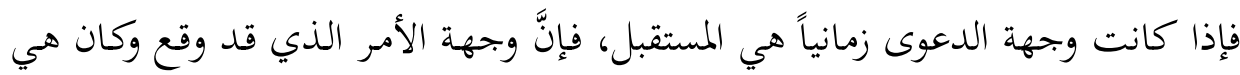

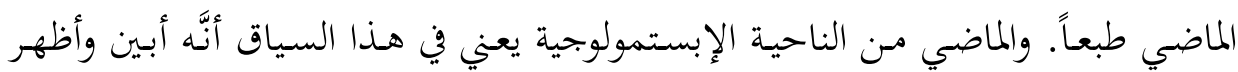

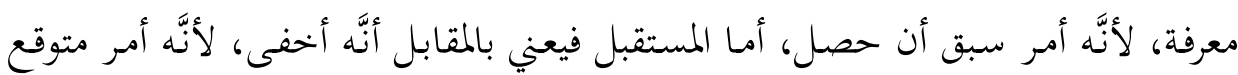

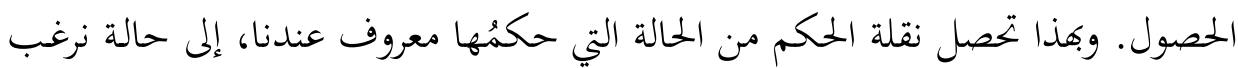

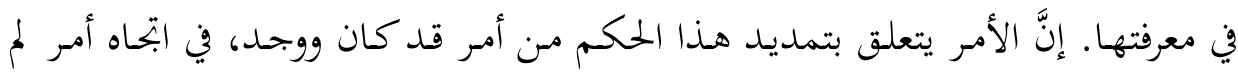

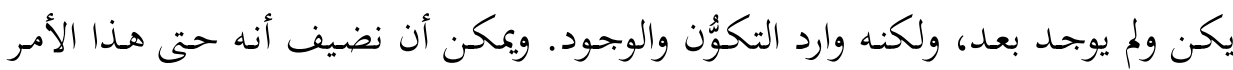

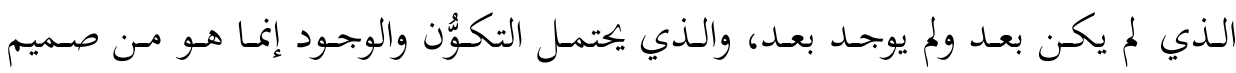

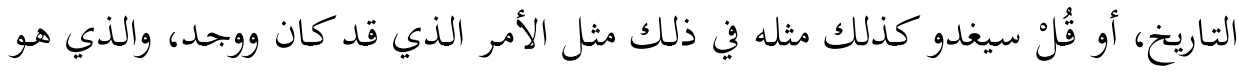
مستقى من حدث تاريخي حقيقي لأجل التدليل على ضرورة تفادي أمر لا نريد حصوله تاريخياً.

المثال الذي يتمثل به هنـا هو إذن أمر قد كان ووجد فعلاً، في مكان بعينه وزمان

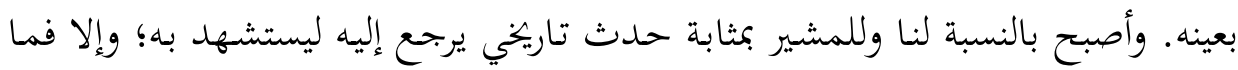

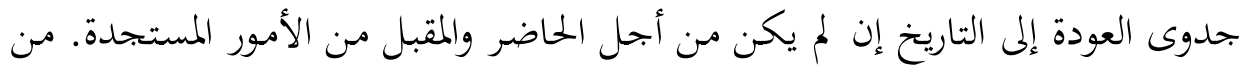

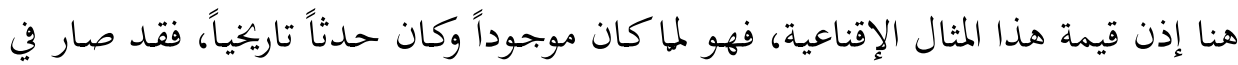




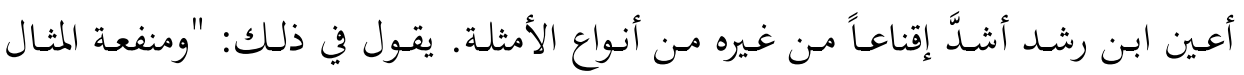

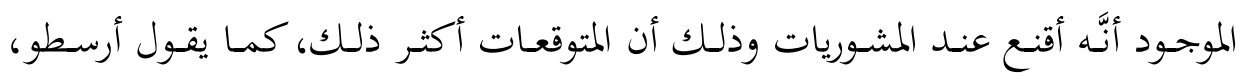

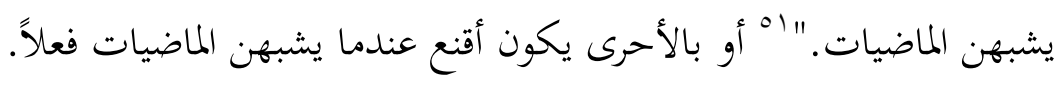

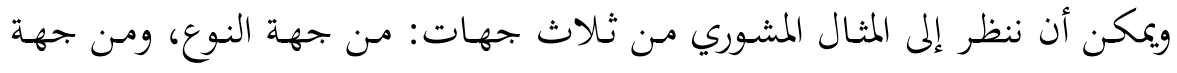

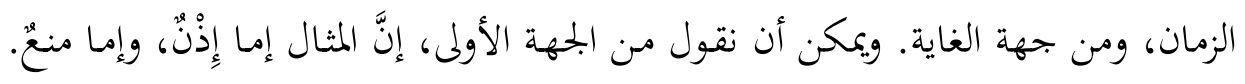

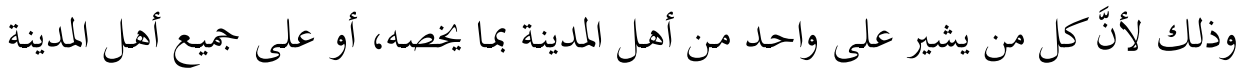

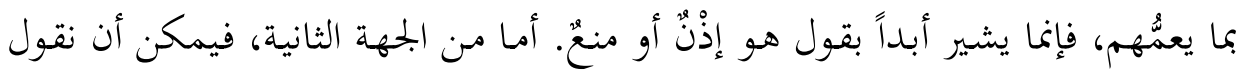

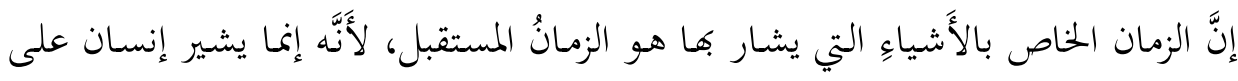

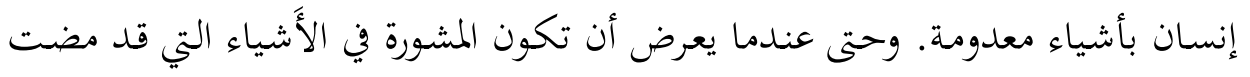

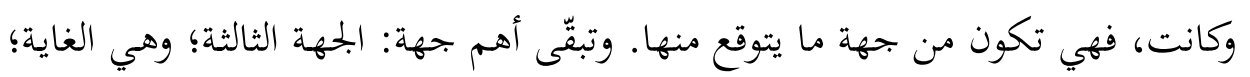

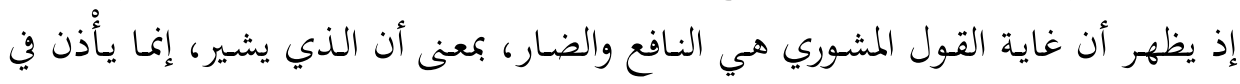

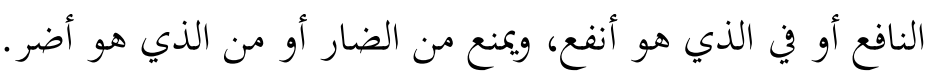
عندما نحلل المثال الذي أورده ابن رشد يتضح مباشرة أنه من نوع المنع، وزمانه زمان

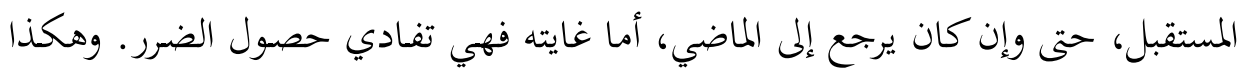

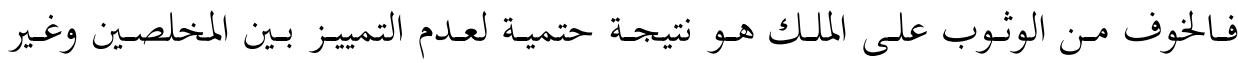
المخلصين في الحرس، بل ولتعيين حارس من غير المخلصين. لكن التخوف مس المن اغتيال

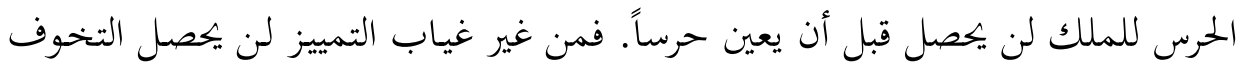

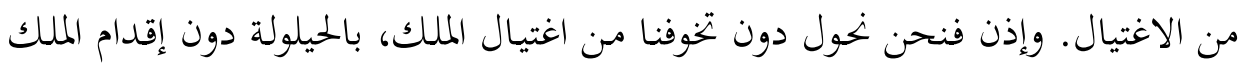
على تعيين حرس دون تمييز بين النصحاء منهم وغير النصحاء. على الخطيب أن يشير على هذا الملك المتمل عندما يكون بصدد الإعداد لتعيين

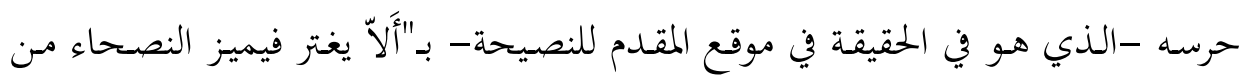

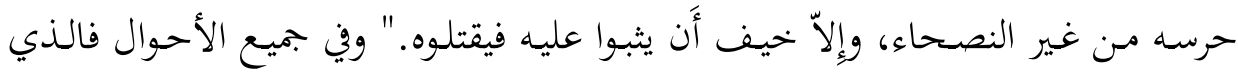

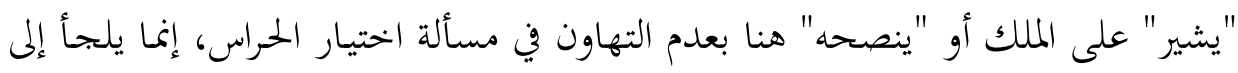


التاريخ، بما هو ديوان العبر، ليستشهد بواقعة تاريخية فعلية، وهي "ما عرض للمتوكل من

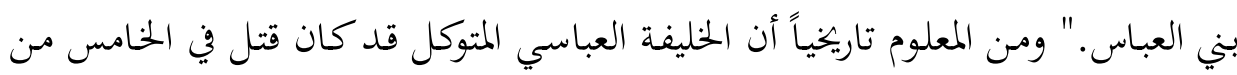

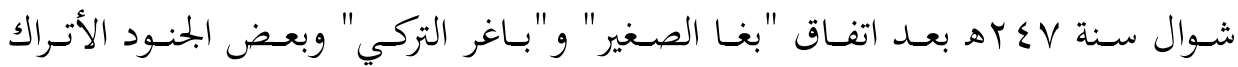
للتخلص مـن المتوكل وتنصيب ابنه المنتصر، فـدخل عليه خمسة مـن هؤلاء الجنود ليلاً فقتلوه.

صحيح أن ابن رشد قد استعاد المناخ العام للمثال (وهو مناخ المشورة) الذي صور به أرسطو الاستقراء، لأجل التمثيل به لأقواله؛ أعني أقوال ابن رشد، لكندا لكنه فعل ذلك الك دون

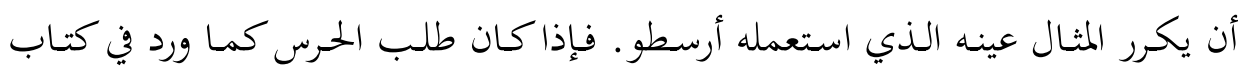

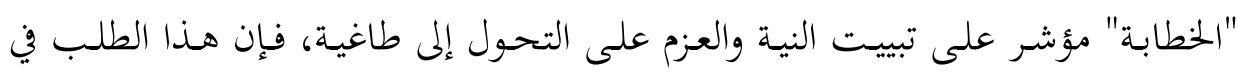

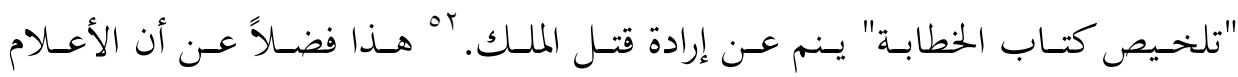

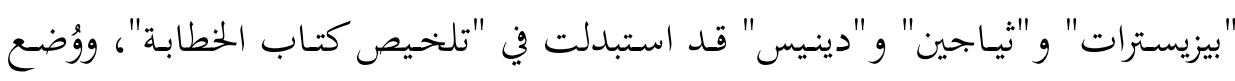

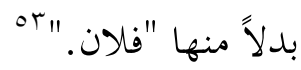

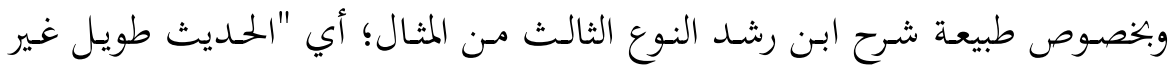

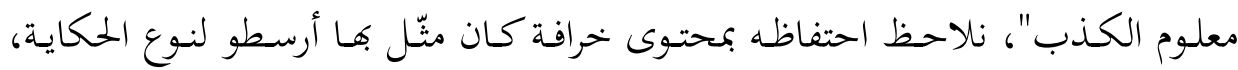

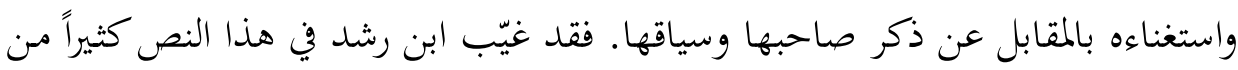

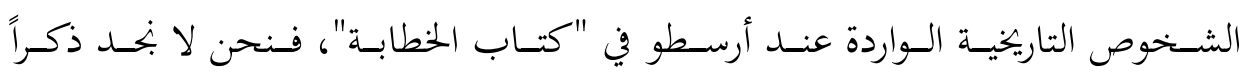

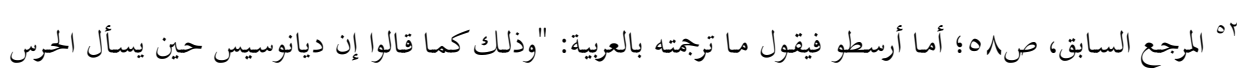

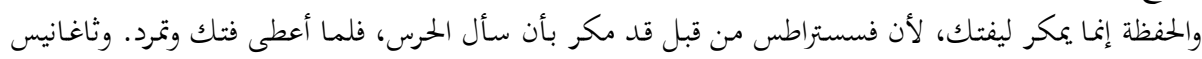

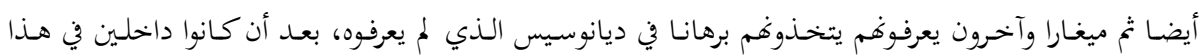

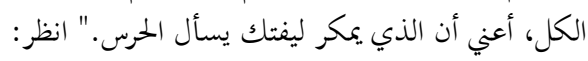

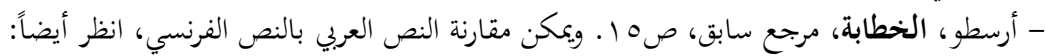

- Aristote, Rhétorique, trad. du grec ancien par Médéric Dufour et André Wartelle, Paris: Gallimard, 1998, 1357b, p.28.

${ }^{53}$ Aristote, Ibid.

$$
\text { وبخصوص الاختلافات بين نص ابن رشد ونص أرسطو: }
$$

- Maroun Aouad, In Averroès, Commentaire moyen à la Rhétorique d'Aristote, (Vol. III: Commentaire du Commentaire), Paris: Vrin, 2002 , p 59. 
لستزيشور؛ الرجل الذي أشار إليه ابن رشد "ببعض القدماء"؛ وفالاريس وهو المشار إليه

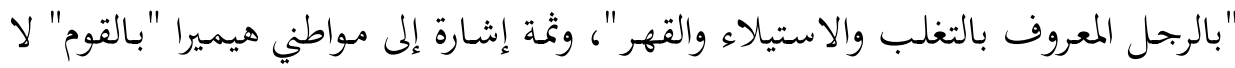
غير .

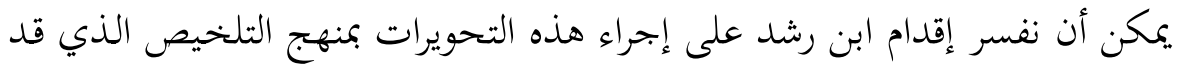

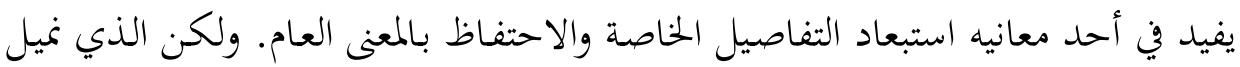

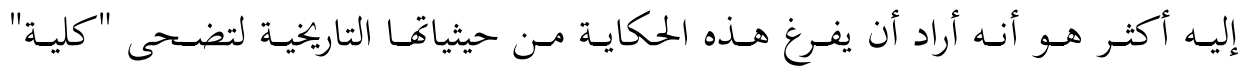

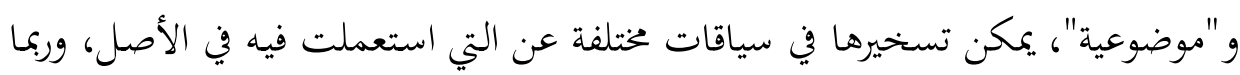

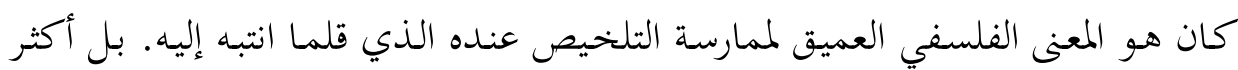

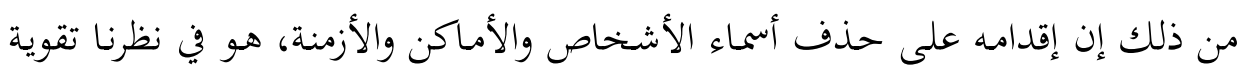
للقيمة الإقناعية للحديث الطويل.

ويمكن القول إنَّ استبدال ابن رشد فلاناً بهذه الشخوص وتعويضها، إنما هو نوع من

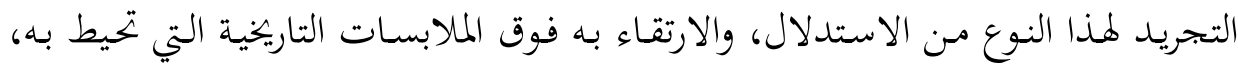
التي هي سر نسبيته ومحدوديته في آن معا. ومسن هنا، فإن الحمديث عن فلان في المطلق،

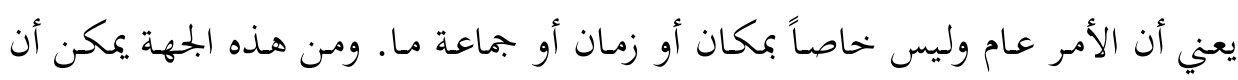

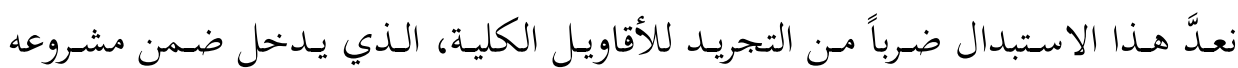
العلمي عامة.

ويجدر بنا أن نشير إلى أن ابن رشد، في تمثيله للشاهد التاريخي الذي هو النوع الأول

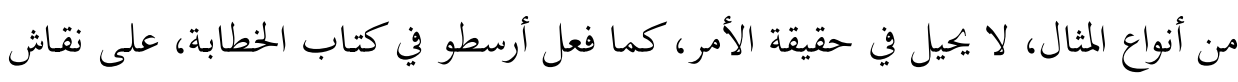

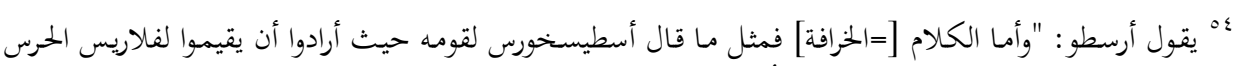

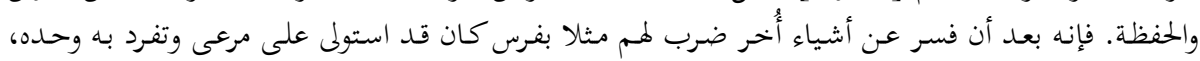

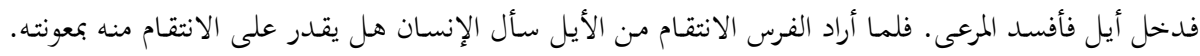

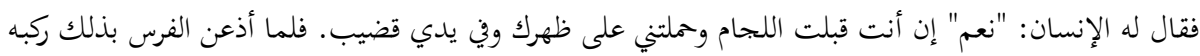

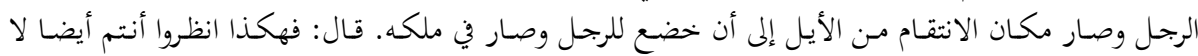

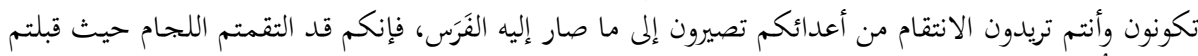

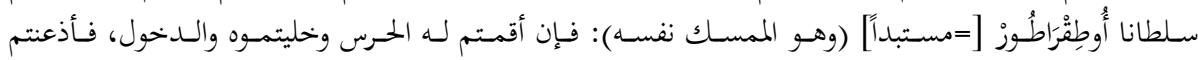

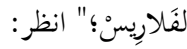

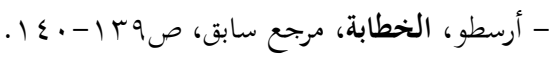




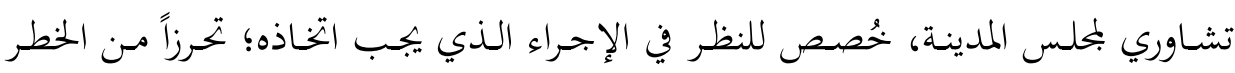

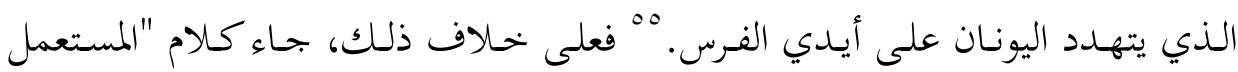
للأمور التي قد كانت ووجدت" الذي ورد على لسان ابن رشد، في صيغة بحردة أقرب إلى الى الفيل

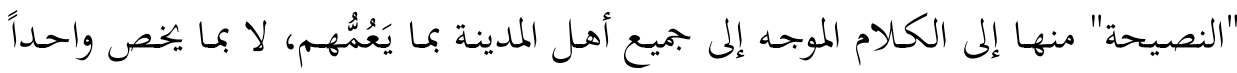

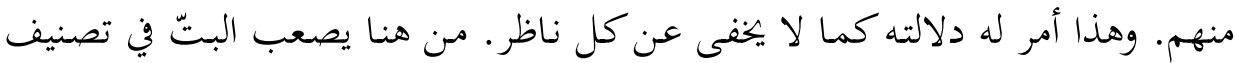

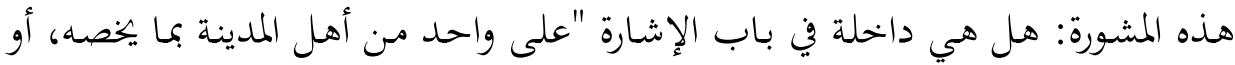

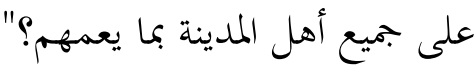

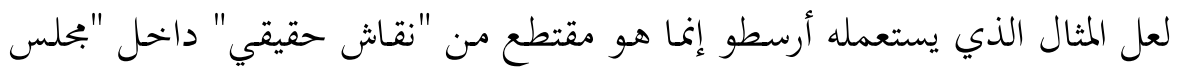

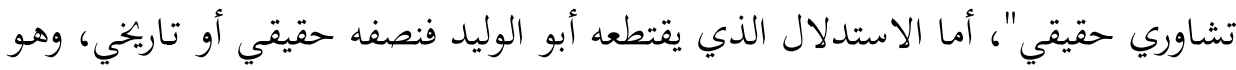
الماضي منه؛ أما المخاطب بهذا الأمر الذي مضى فهو غير مشار إليه، إنه ملك وكفى.

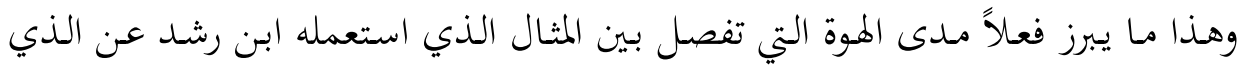

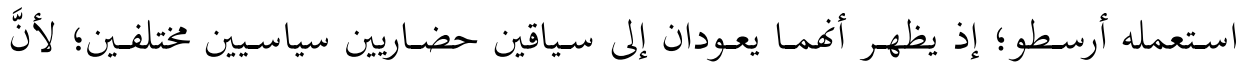

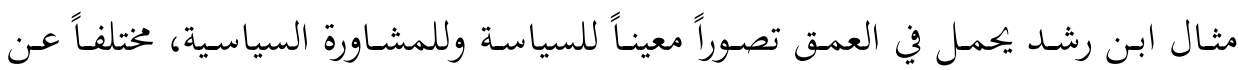

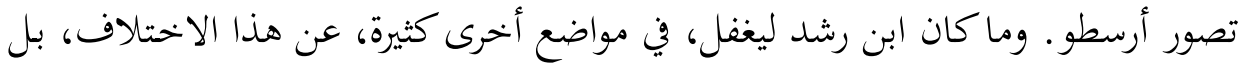

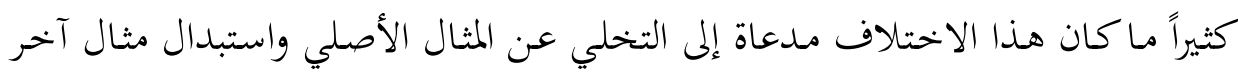

لكن استعادة ابن رشد للشواهد السابقة -وأخرى لم نذكرها- في شروحه لا يعني أن

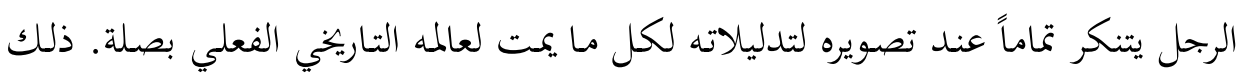

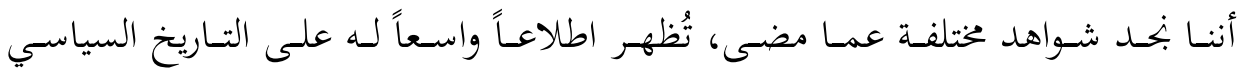

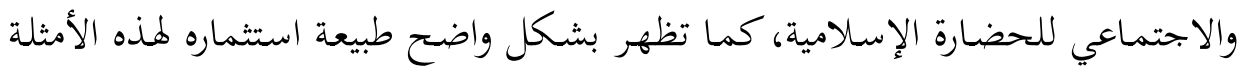

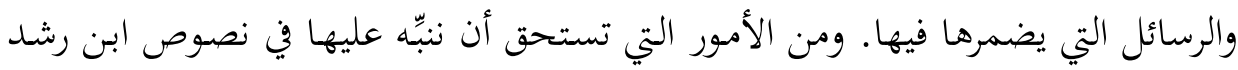

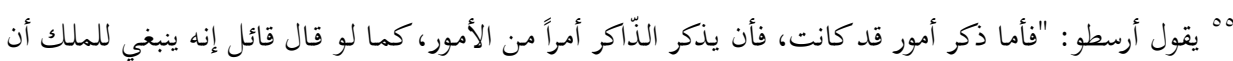

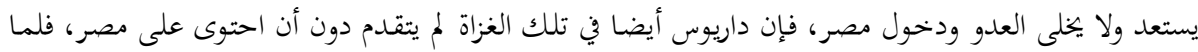

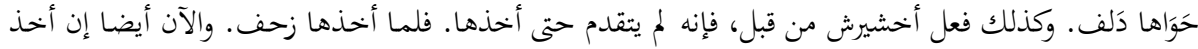

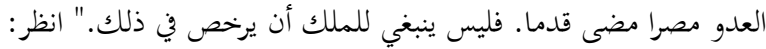

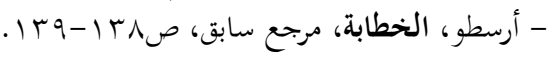


تلـك الغزارة والتـققيق في التصوير التـاريخي، وبخاصـة مـا يتعلق بتـاريخ الأنـلس المعاصر

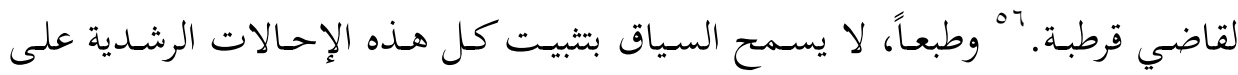

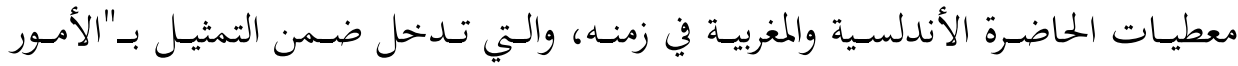

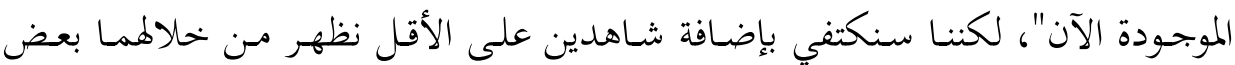
مواقف ابن رشد السياسية والاجتماعية.

\section{Y ب. الموقف من ساسة الأندلس:}

يظهر من خهال بعض الأمثلة التي استعملها ابن رشد في "تلخيص كتاب الخطابة" أنه كان صاحب رؤية معينة في تحليل الأحداث السياسية لمدينته. يقول في هذا السياق:

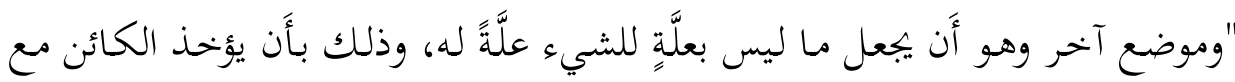
الشيء أَو بعده سبباً لوجود الشيء من غير أَ أن يكون سبباً. فإن الخطباء يستعملون مـاء

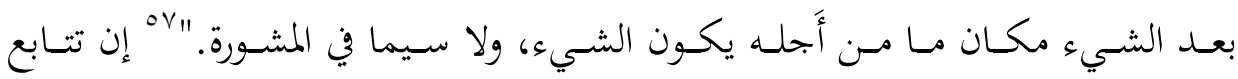

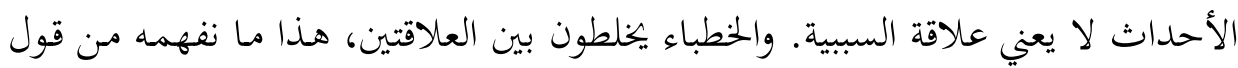

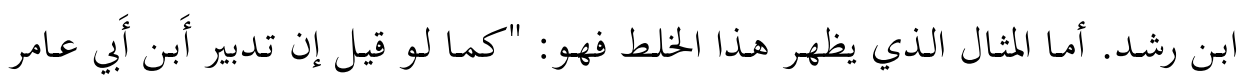

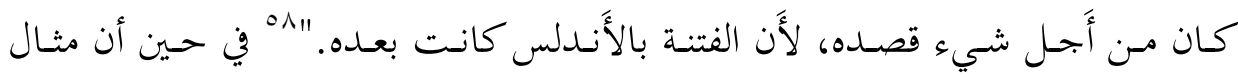

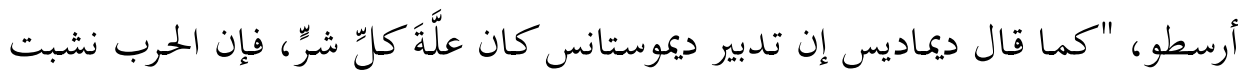

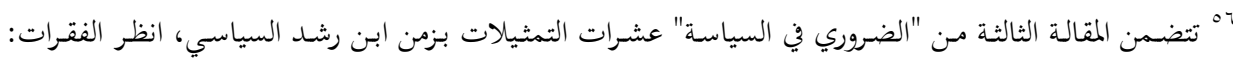

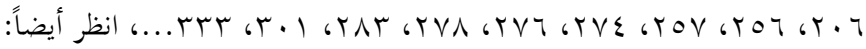

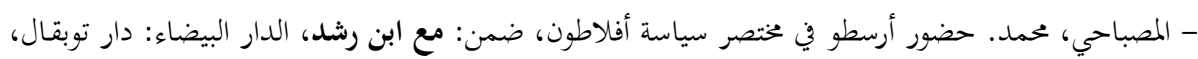

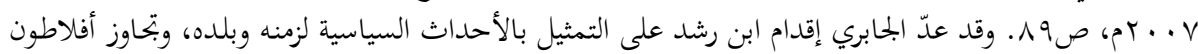

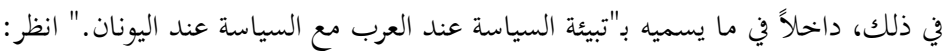

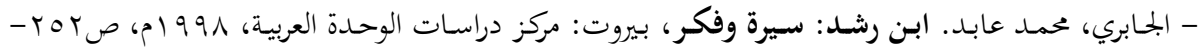
roV

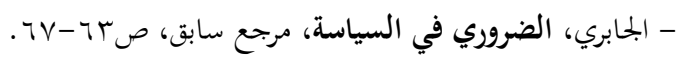

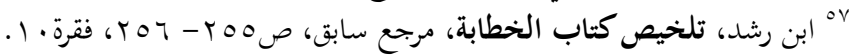

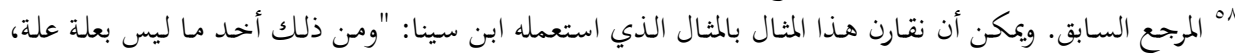

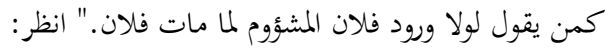

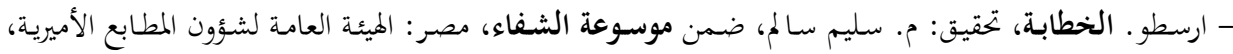


بعد ذلك." وهكان ابن رشد مطالباً أولاً بمعرفة التاريخ اليوناني وأنظمة التدبير والمشيرين حتى يتمكن من بسط هذا المثال الذي استعمله أرسطو؛ وهو فضلاً عن ذلك قد الد لا يعني الشيء الكثير عند مخاطب ابن رشد، إن هو بسّطه له. والقاعدة في المثال هي أن تكون

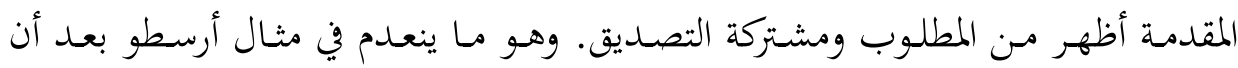

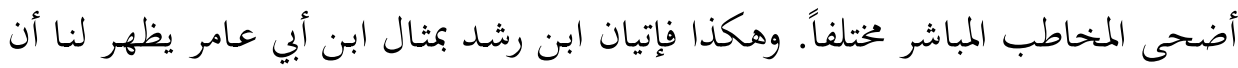

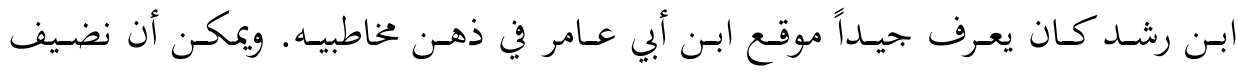

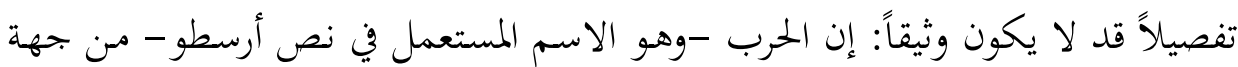
الإيحاء ليس هو الفتنة؛ لأنَّ هذا يستدعي تداعيات حضارية خحاصة بالمخحاطبين المسلمين

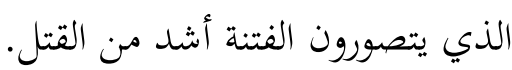

وقد كان مثال ابن أبي عامر موضوع تعليق من قبل بعض الدارسين، الذين انتبهوا إلى خطورة الأمثلة التاريخية في الخطاب الفلسفي لابن رشد. يقول بنشريفة: "هـا مثال

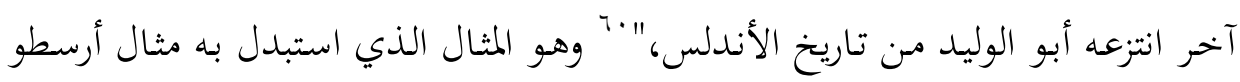
المذكور أعلاه. ويضيف: "أمـا تدبير المنصور بن أبي عامر الذي مثّل به ابن رشد فلعله

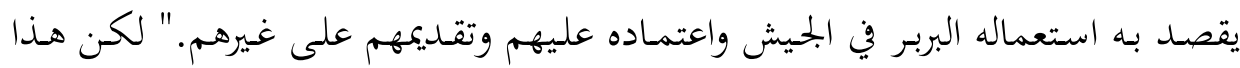

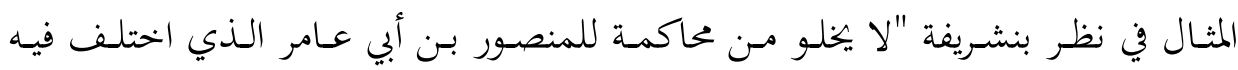

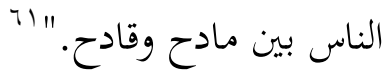
أمـا مارون عواد فيعدّ الصيغة التي جاء بهـا مثال ابن رشد تحمل في طياتَا نوعاً مـن

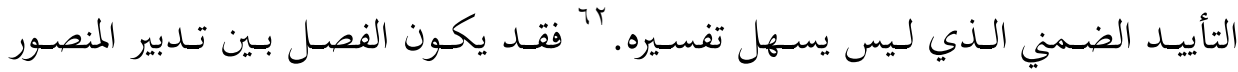

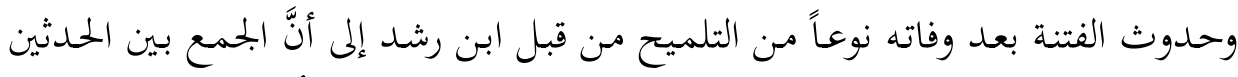

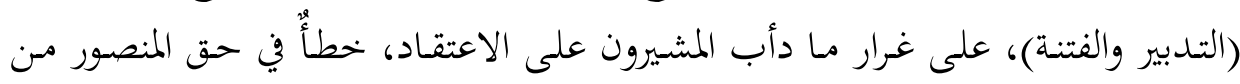

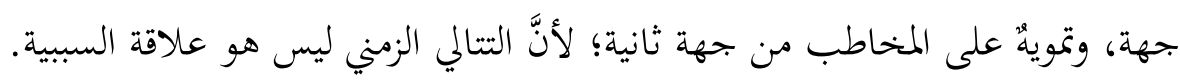

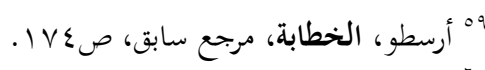

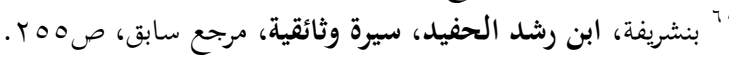

$$
\begin{aligned}
& \text { " المرجع السابق. الصفحة نفسها. }
\end{aligned}
$$

${ }^{62}$ Aouad, Maroun. Op. Cit., p. 234-235. 
لماكان معروفاً أن المشورة تتوج بالفعل أو بالتَّكك أساساً، فإننـا يمكن أن نفهم مـن

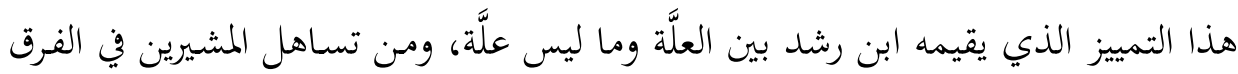

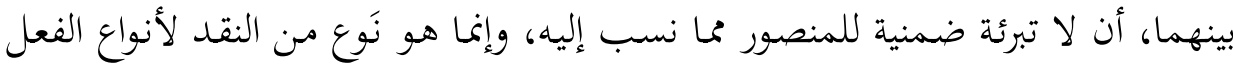
والترك السياسيين، اللذين يعتمدان مشورة يفتقر أصحابها للأهلية في تحليلهم للأحداث

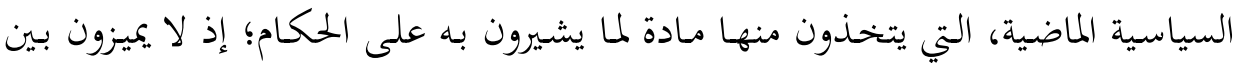

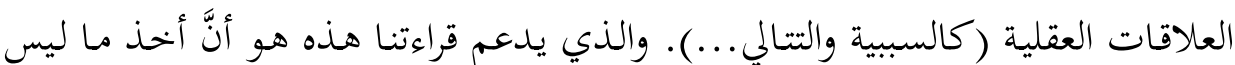

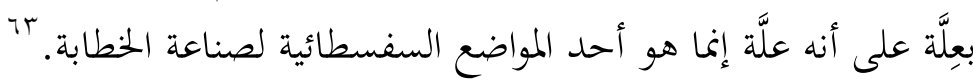
ومع أن ابن أبي عامر هذا لم يكن حاضراً في نص ابن رشد في هذه المرة، فقد كانت

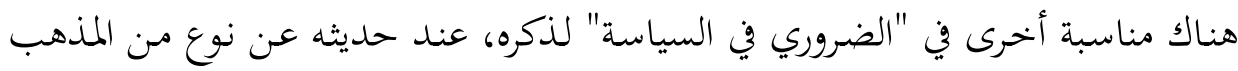

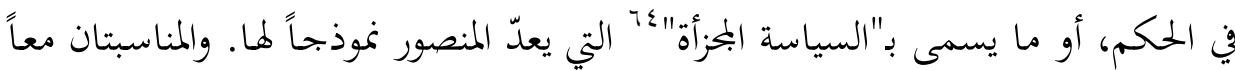

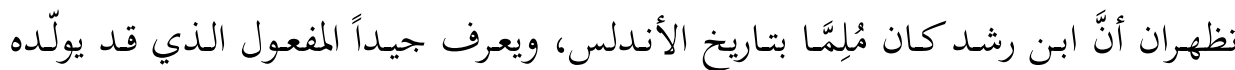
هذا المثال في ذهن الأندلسيين المعاصرين له.

وهكذا يكشف تقديم ابن رشد أمثلة من تاريخ المغرب والأندلس أثناء حديثه عن

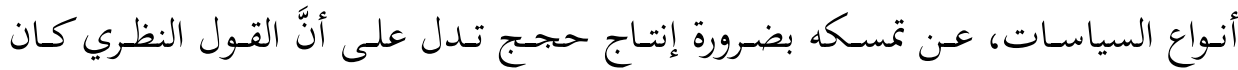
مشدوداً بالحالات الجزئية. فمن الواجب توفير مواد للحدود والمذاهب السياسية، لا لأهَّا

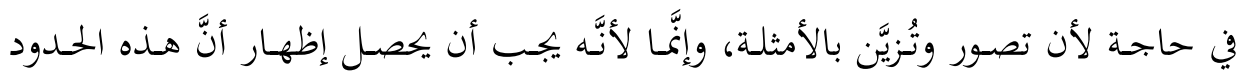
والمذاهب تأخذ المسارات التاريخية الواقعية بعين الاعتبار.

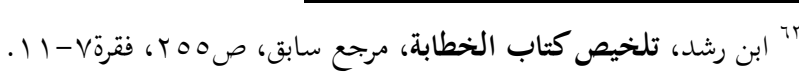

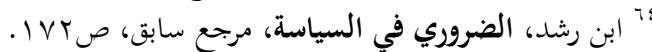

65 Gerbier, Laurent. «La politique et la médecine: une figure platonicienne et sa relecture averroïste », Astérion [En ligne], 1 | 2003, mis en ligne le 04 avril 2005, consulté le 16 mars 2013. URL: http://asterion.revues.org/13.

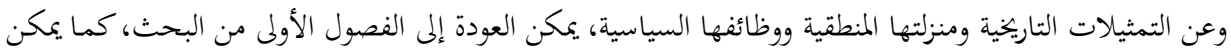

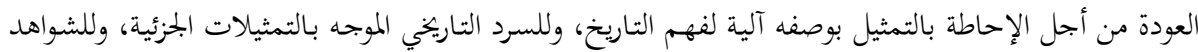

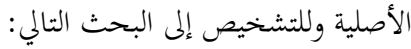

- Canfora, Luciano et Fourgous, Denise. La tolérance et la vertu. De l'usage politique de l'analogie, Paris: Desjonquères, 1992, pp. 23-81. 
وفضلا عمَّا سبق، فإنَّ إتيان ابن رشد بأمثلة تحمل تقويمات سياسية ورؤى نقدية هو أمر يظهر نوعاً من الانخراط المدني لابن رشد، بجهة ما، في صياغة قراءة معينة لهذا التاريخ

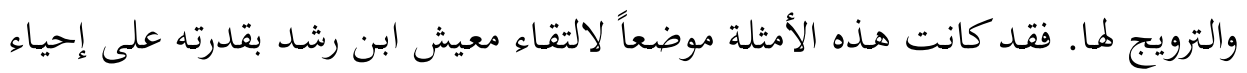

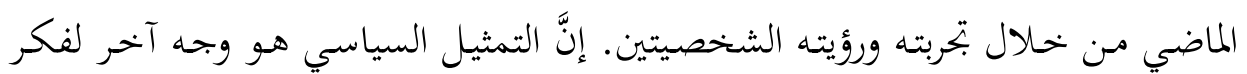

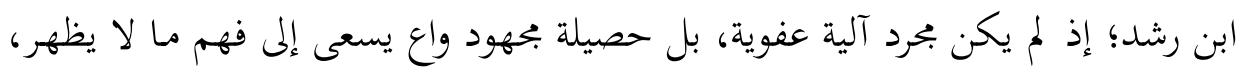

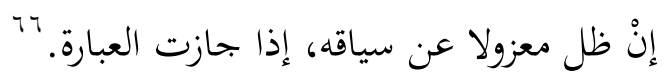

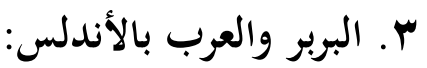

مس المعـروف أنَّ الخطابـة تمستُّ في أحسد جوانبها بحـال الانفعالات، للذلك كان ابن

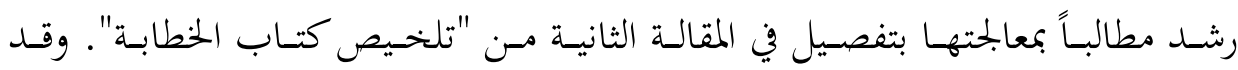

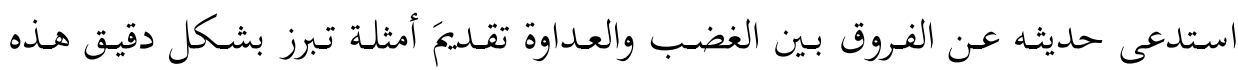

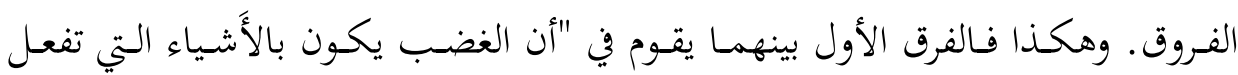

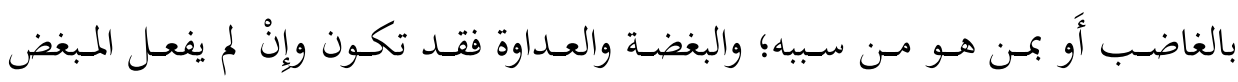

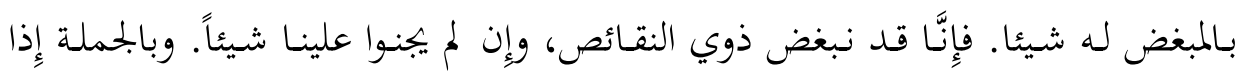

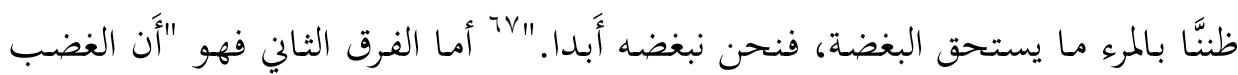

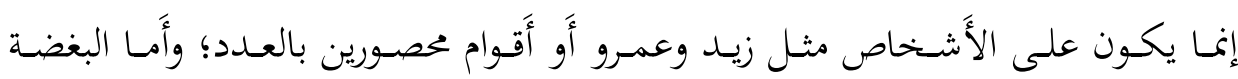

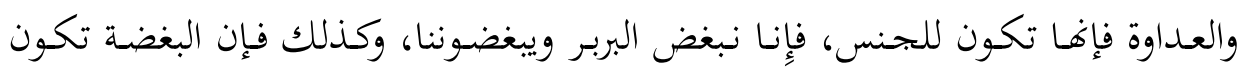

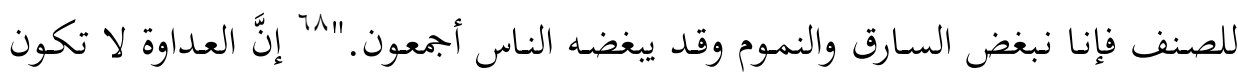

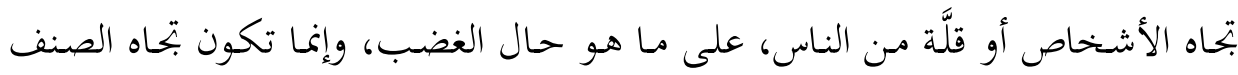
والجنس الذي يتخذ هنا معنى عرقياً.

ويمكن أن نلاحظ منذ البداية أن ابن رشد قد أجرى على النص الذي يشرحه هنا

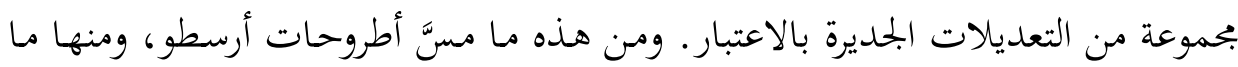
مسَّ الأمثلة التي استعملها هذا الأخير في توضيح أطروحاته:

${ }^{66}$ Ibid, pp.31, 37.

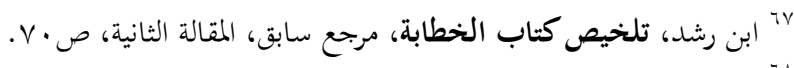

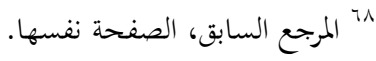


فابن رشد "يضيف إلى الغضـب على الأفراد الغضب على جماعـة من الناس. ويميز

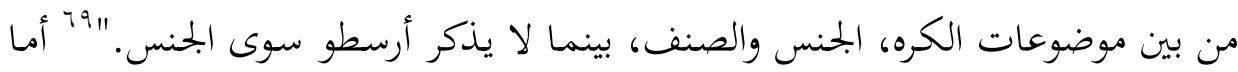

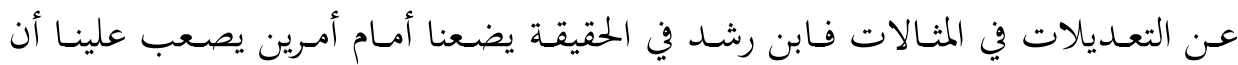
نفسر كيف جمع بينهما. فهو عند شرحه الموضع الذي يتكلم فيه أرسطو عن الغضب لفي

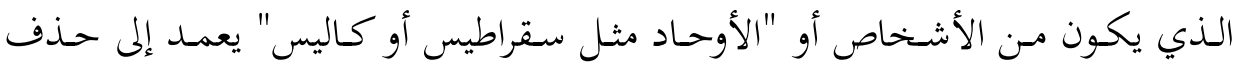

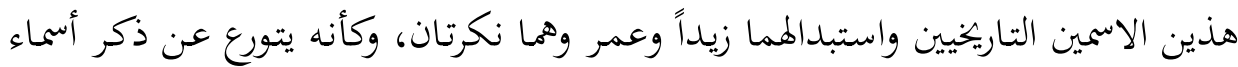

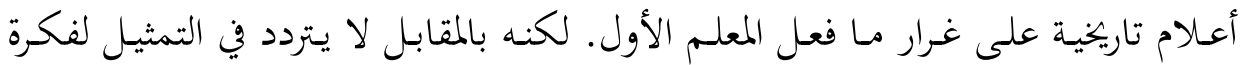

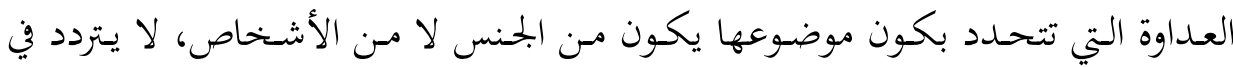

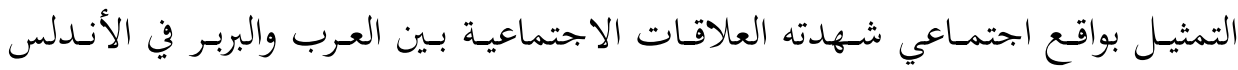

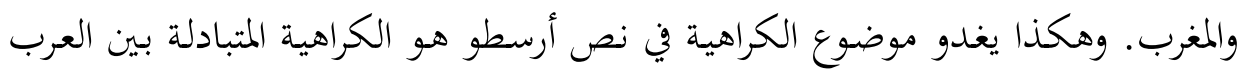
والبربر في نص ابن رشد.

يقول محمد بنشريفة في تعليقه على تمثيل ابن رشد: "قد يستغرب هذا المثال من ابن

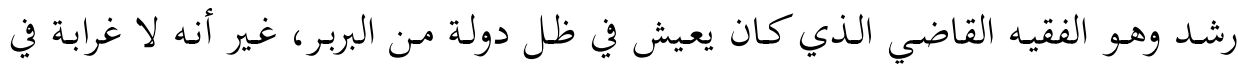

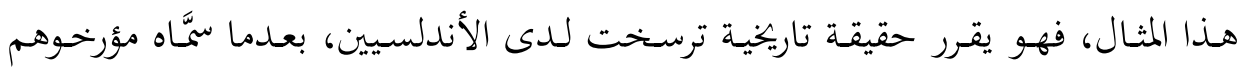

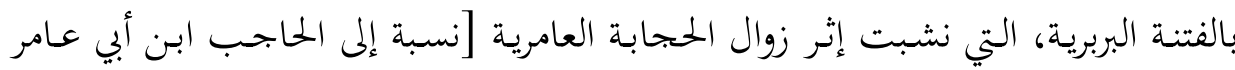

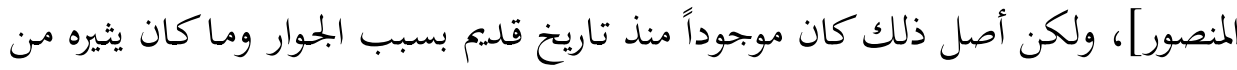

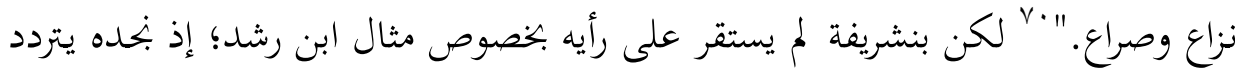

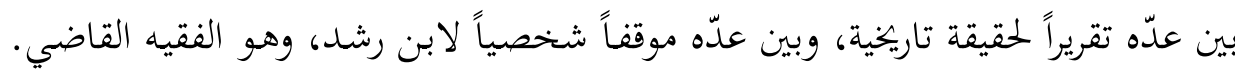

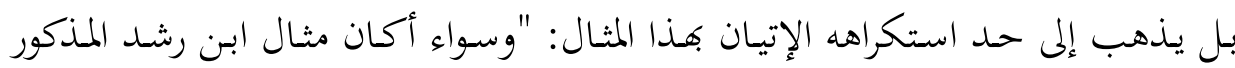

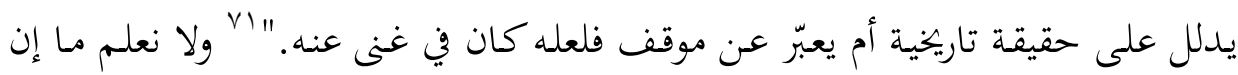

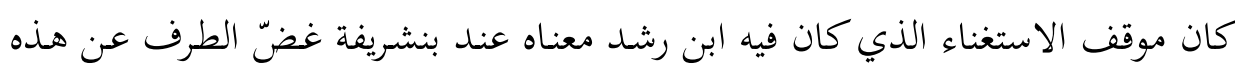
الحقيقة التاريخية المعلومة جيداً عنده، أم أن ابن رشد كان مطالبا بان فالحياد حتى في أمثلته. ${ }^{69}$ Maroun Aouad, Op. Cit., p. 24. 
وإذ نعدّ المثال أمراً لا حياد فيه؛ إذ هو من إعادة بناء المتمثل، حتى وإن كان الأمر

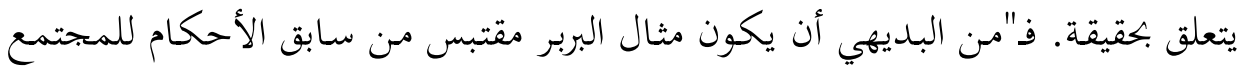

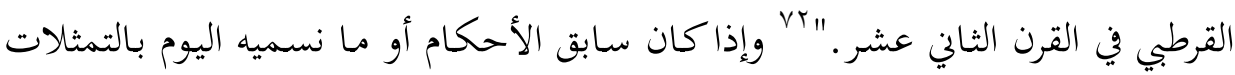
الاجتماعيـة هـي حصـيلة بنـاء تتفاعـل فيـه بحموعـة مـن الشـروط الاجتماعيـة والثقافيـة

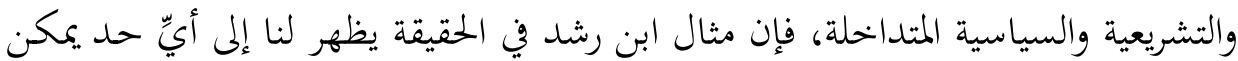
أن تتغلغل هذه التمثلات في الخطاب الفلسفي.

\section{خاتمة - ماتمة}

نخلص مما سبق، أن نصوص ابن رشد الفكرية ليست مدخحلاً لفهم نمط تفكير ابن

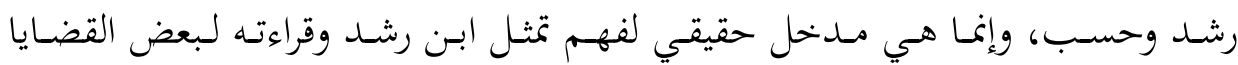
الدينية، والأحداث التاريخية، والمسلكيات الاجتماعية، وطريقة استعادته لها في نصوصه.

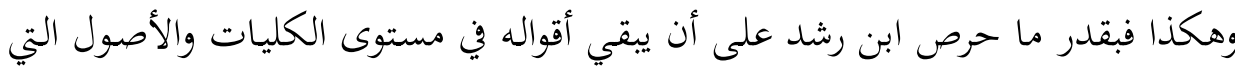

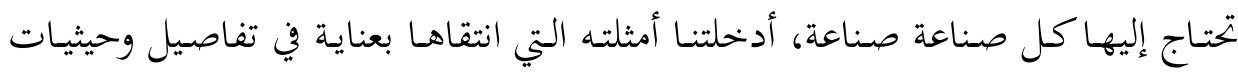
تاريخية لا تكشف عن مواقف سياسية واجتماعية لابن رشد وحسب، وإنما عن تمثلاته ورغباته أيضاً.

إنَّ سعي ابن رشد إلى تأكيد أطروحاته بالاعتماد على شواهد تاريخية، دليل على

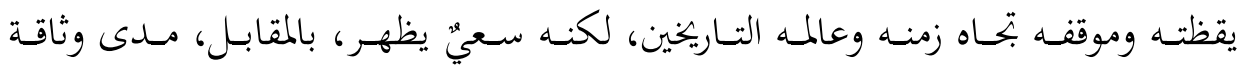

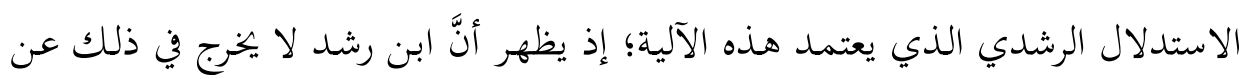

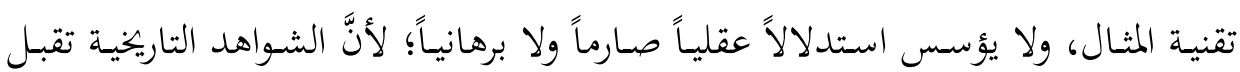

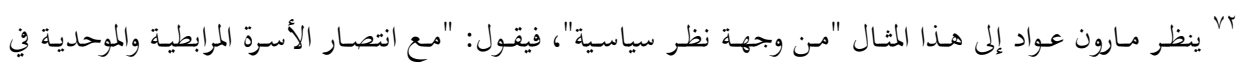

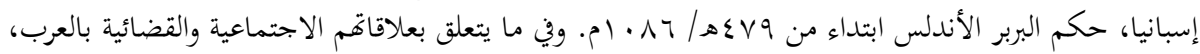

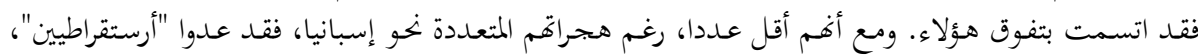

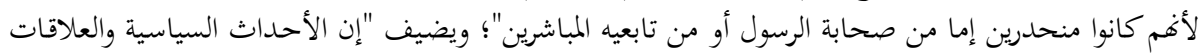

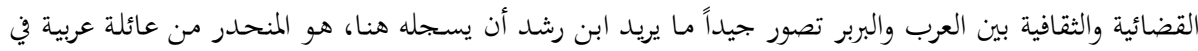

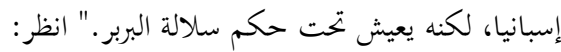

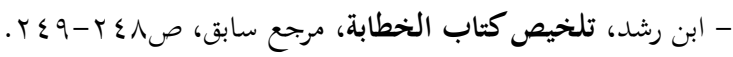


قراءات ليست متوافقة بالضرورة، وذلك حسب زوايا النظر وصراعات القوى المتحكمة في هذه الزوايا.

إنَّ الدرس الذي يمكن أن نستخلصه من الصفحات السابقة هو أن الفيلسوف ابن رشـد لم يكـن في كتاباته الفلسفية والعلميـة والمنطقيـة منغلقـاً كليـة عـن مجريـات التـاريخ.

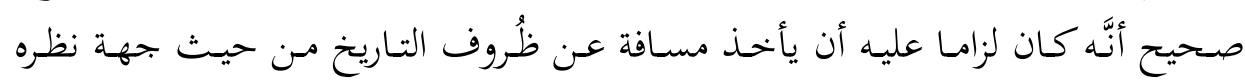

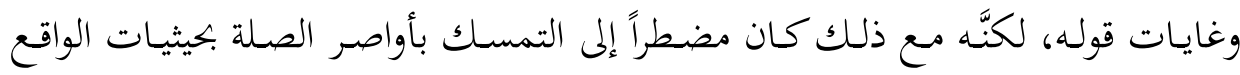

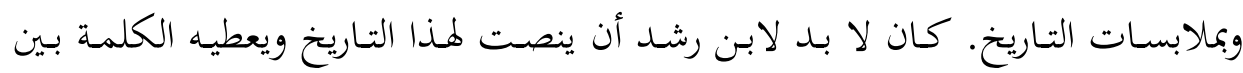

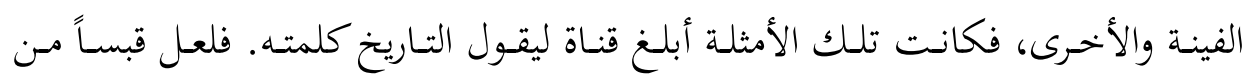
التاريخية لم يغادر فكر أبي الوليد. 